\title{
Ground-dwelling Songbirds as Reservoirs and Carriers of Tickborne Disease (Lyme Disease)
}

Amanda Jayne Hill

Follow this and additional works at: https://researchrepository.wvu.edu/etd

\section{Recommended Citation}

Hill, Amanda Jayne, "Ground-dwelling Songbirds as Reservoirs and Carriers of Tickborne Disease (Lyme Disease)" (2018). Graduate Theses, Dissertations, and Problem Reports. 7188.

https://researchrepository.wvu.edu/etd/7188

This Thesis is protected by copyright and/or related rights. It has been brought to you by the The Research Repository @ WVU with permission from the rights-holder(s). You are free to use this Thesis in any way that is permitted by the copyright and related rights legislation that applies to your use. For other uses you must obtain permission from the rights-holder(s) directly, unless additional rights are indicated by a Creative Commons license in the record and/ or on the work itself. This Thesis has been accepted for inclusion in WVU Graduate Theses, Dissertations, and Problem Reports collection by an authorized administrator of The Research Repository @ WVU. For more information, please contact researchrepository@mail.wvu.edu. 


\title{
Ground-dwelling Songbirds as Reservoirs and Carriers of Tick- borne Disease (Lyme Disease)
}

\section{Amanda Jayne Hill}

Thesis submitted

to the Davis College of Agriculture, Natural Resources, and Design at West Virginia University

in partial fulfillment of the requirement for the degree of

Master of Science in Animal Physiology

\author{
Christopher Lituma, Ph.D., Co-chair \\ Matthew Wilson, Ph.D., Co-chair \\ Jean Meade, Ph.D., DVM, MD
}

Department of Animal Physiology

\author{
Morgantown, West Virginia \\ 2018
}

Keywords: Lyme disease, tick-borne disease, songbirds, carriers Copyright 2018 Amanda Jayne Hill 


\begin{abstract}
Ground-dwelling Songbirds as Reservoirs and Carriers of Tick-borne Disease (Lyme Disease)
\end{abstract}

\title{
Amanda Jayne Hill
}

The One Health initiative, focused on increasing interdisciplinary collaboration amongst the fields of human medicine, veterinary medicine, and environmental health, considers zoonotic diseases to be a primary concern due to their impact on humans, animals, and the environment. Lyme disease is the most common vector-borne zoonosis in the United States. It is spread through interactions between ticks and several hosts, including small and large mammals, birds, lizards, and humans. Both Borrelia burgdorferi (causative agent of Lyme disease) and Ixodes scapularis (primary vector for Lyme disease in the Northeastern United States) are expanding their ranges. Our goal is to understand the potential role that ground-dwelling songbirds play in the spread of Lyme disease through studying infestation rates and reservoir competency. We examined birds of 14 focal ground-dwelling species at banding stations in New York, Pennsylvania, and West Virginia during the Spring and Fall migrations of 2017. We removed ticks (nymphs) from all infested birds and collected blood from a random sample of both infested and non-infested birds. The prevalence of ticks on birds was $35.6 \%(n=371)$. Of the 270 ticks removed from infested birds and tested, $26.7 \%$ were qPCR positive for Borrelia burgdorferi. We detected Borrelia burgdorferi in 7.9\% $(n=178)$ of avian blood samples. Through modeling, we found associations between bird life-history characteristics (age, fat score, phylogenetic family, and migratory strategy) and infestation, tick load, or infestation by Borrelia burgdorferi positive ticks. 


\section{ACKNOWLEDGEMENTS}

I would like to thank my committee members for giving me the opportunity to conduct this research and helping me grow as a student and a researcher. I would like to thank Dr.

Christopher Lituma for taking a chance on me, guiding me through the research and writing process, and introducing me to the world of wildlife. Also, I would like to thank Dr. Matthew Wilson for inspiring me to pursue a degree in animal physiology and helping me through every step of the graduate process. I would also like to thank Dr. Jean Meade for motivating me to pursue my masters, helping me develop this One Health research project, and making it possible for me to experience all that the world of veterinary medicine has to offer. I am grateful to Luke DeGroote and Mary Shidel at the Powdermill Avian Research Center, Andrea Patterson at the Braddock Bay Bird Observatory, Todd Schnopp at the Allegheny Front Migration Observatory, and all of the technicians and volunteers at each station for welcoming me to their banding stations and making this research possible. In addition, I would like to thank Dr. Brian Hendricks for helping me design this study and teaching me all of the lab techniques necessary to complete it. I would also like to thank Dr. Jesse Fallon for teaching me how to handle birds and giving me the opportunity to gain experience with them. I am grateful to Dr. Scott Bowdridge for letting me use his lab and teaching me how to use the equipment. Lastly, I would like to thank my family for supporting me in everything that I do and always inspiring me to achieve more. 


\section{TABLE OF CONTENTS}

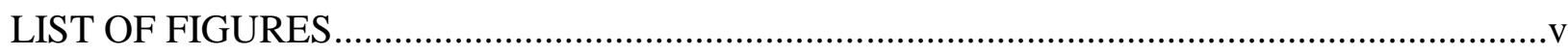

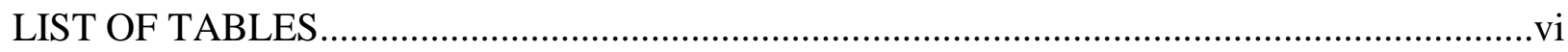

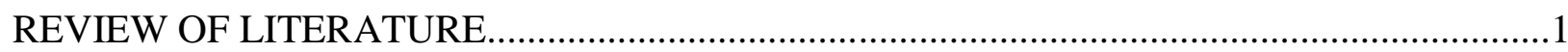

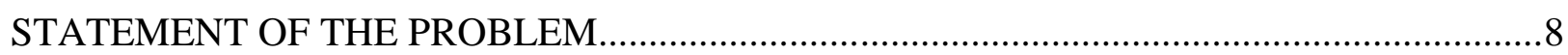

CHAPTER 1: FACTORS AFFECTING TICK INFESTATION OF SONGBIRDS IN THE

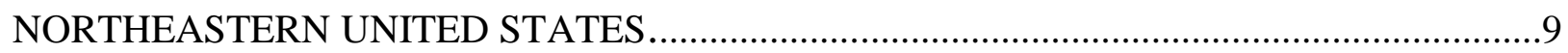

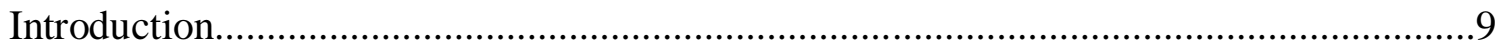

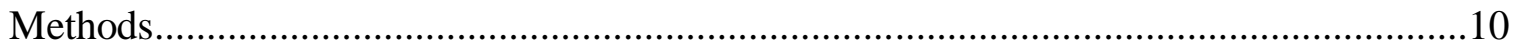

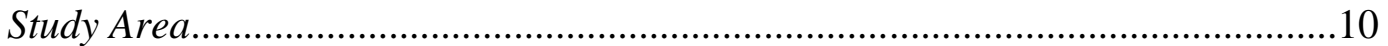

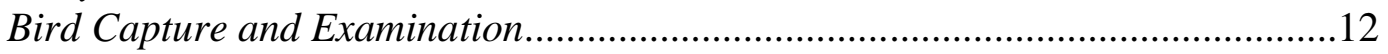

Tick Infestation and Tick Load...........................................................................13

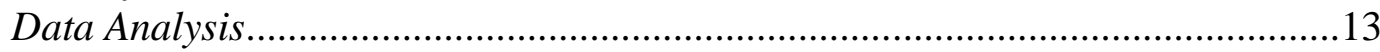

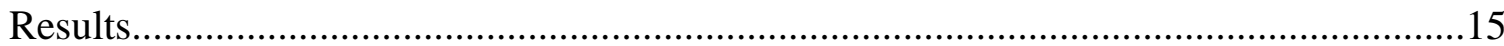

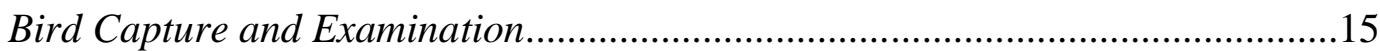

Tick Infestation and Tick Load.................................................................... 15

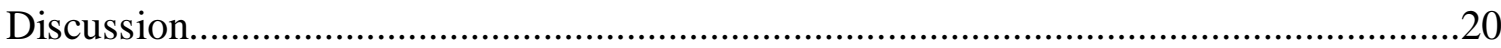

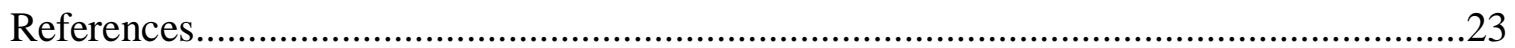

CHAPTER 2: GROUND-DWELLING SONGBIRDS AS RESERVOIRS AND CARRIERS OF

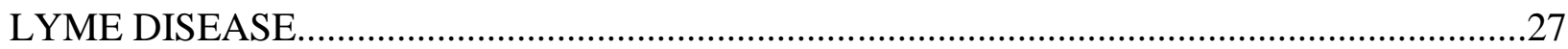

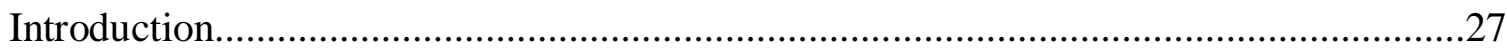

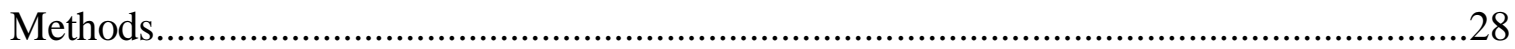

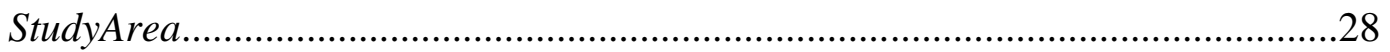

Bird Capture and Focal Species Sampling ...................................................29

Pathogen Screening and Tick Speciation.........................................................30

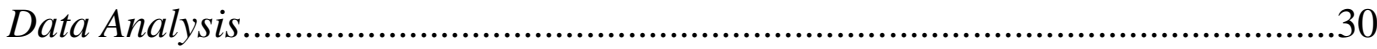

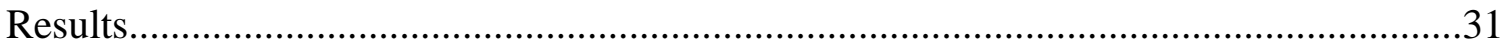

Bird Capture and Focal Species Sampling ......................................................

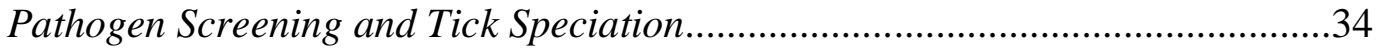

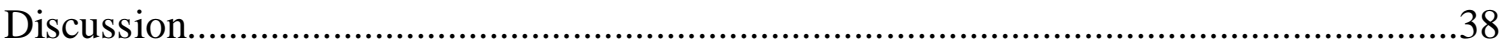

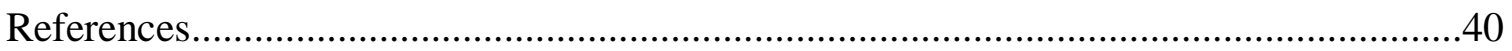

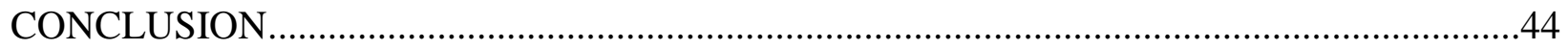

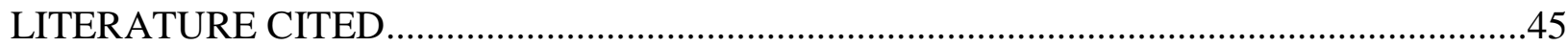




\section{LIST OF FIGURES}

Figure 1-1. Logistic regression results for infestation. Predicted relationship from logistic regression of the association between probability of infestation by age and fat score.

Figure 2-1. Logistic regression results for Borrelia burgdorferi positive tick threshold. Logistic regression of probability of finding a Borrelia burgdorferi positive tick base on the number of ticks present on a bird.

Figure 2-2. Logistic regression results for infestation by a Borrelia burgdorferi positive tick. Logistic regression of association between fat score and probability of removing a Borrelia burgdorferi positive tick form a bird.

Figure 2-3. Infestation summary by species. Proportion of birds not infested, infested, or infested by Borrelia burgdorferi positive ticks based on species. .36 


\section{LIST OF TABLES}

Table 1-1. Information on 14 focal species. Details about the 14 species being examined including the common name, scientific name, family, and migratory strategy.

$* \mathrm{R}=$ resident, $\mathrm{SM}=$ short-distance migrant, $\mathrm{LM}=$ long-distance migrant

Table 1-2. Categorical variables. Description of categorical variables being tested for associations with infestation and tick load.

Table 1-3. Infestation results. Summary of samples examined (birds) and collected (ticks) by species in PA, NY, and WV during the spring and fall migrations of 2017.

Table 1-4. Logistic regression results for infestation. Significant logistic regression statistics for association between infestation probability and the bird characteristics age and fat score in PA, NY, and WV during the spring and fall migrations of 2017.

Table 1-5. Model selection results for infestation. AIC Table reporting on top competitive models of infestation (age+fat, age+fat+season, age, age*fat) in birds examined in PA and NY during the spring and fall migrations of 2017.

Table 1-6. Negative Binomial regression results for tick load. Significant negative binomial statistics for association between tick load and the bird characteristics age, fat score, phylogenetic family, and migratory strategy.

Table 2-1. Logistic regression results for infestation by a Borrelia burgdorferi positive tick. Significant parameter estimates from logistic regression models for associations between the probability of removing a Borrelia burgdorferi positive tick and the significant bird characteristic fat score.

Table 2-2. Model selection results for infestation by a Borrelia burgdorferi positive tick. AIC Table reporting on competitive models of infestation by Borrelia burgdorferi positive ticks in PA and NY during spring and fall migration.

Table 2-3. Negative Binomial regression results for number of Borrelia burgdorferi positive ticks. Negative binomial statistics for association between number of Borrelia burgdorferi positive ticks removed and the significant bird characteristic fat score.

Table 2-4. Results by species. Raw data summary of birds examined, ticks collected, and blood samples collected by species in PA, NY, and WV during spring and fall migration. .37 


\section{REVIEW OF LITERATURE}

Zoonotic diseases are bacterial, viral, parasitic, or fungal diseases which are spread between animals and people by a variety of mechanisms. Vector-borne diseases can be transmitted across species through different vectors, including various species of plants, fungi, or arthropods (Gray, 2002). The variety of organisms that are susceptible to infection through contact with these vectors makes them a major concern in the fields of human (Homo sapiens sapiens), animal, and environmental health. With over 20,000 confirmed cases reported annually, Lyme disease accounts for $>90 \%$ of all human documented vector-borne disease in the United States, particularly in the northeast (Hamer, 2010; Centers for Disease Control [CDC], 2016).

Lyme disease is a zoonotic disease that affects wildlife, companion animals, and humans, and it is considered a focal area of research for One Health. The One Health initiative focuses on interdisciplinary collaboration between individuals in the fields of health care for humans, animals, and the environment (Zinsstag, 2005; Food and Agriculture Organization of the United Nations, 2011). One Health aims to establish more efficient and cost-effective techniques to improve research, surveillance, and management of factors, like zoonotic diseases, that affect health across all of these disciplines (Baum et al., 2017).

The complexity of Lyme disease and the susceptibility of both humans and animals demands collaboration between physicians, veterinarians, and ecologists to develop better methods for diagnosing, treating, and preventing this tick-borne disease (Dantas-Torres et al,, 2012). In humans and most non-human animals, Lyme disease can cause severe pain and illness by spreading to the joints, heart, and nervous system of the host if left untreated (CDC, 2016). Lyme disease is very difficult to control and prevent, in both human and veterinary medicine, due to the complexity of its transmission cycle that involves multiple vectors and hosts (Dantas-Torres et al., 2012). Although hard ticks, like those that carry Lyme disease, typically only take a single blood meal and would be expected to stay on a host, the introduction of these ticks into a home could lead to human infestation through transmission by the tick's next developmental stage after it has molted (Dantas-Torres, 2012). From an environmental perspective, Lyme disease can be treated as an ecological system centered around the interactions between the pathogen (diseasecausing bacteria), vectors (ticks that transmit disease), carriers (animals that transport the bacteria), and hosts (infested by the vector). Understanding this interaction within an ecological community would allow for improved monitoring and management of the expansion of the disease. Lyme disease spreads as a result of interactions among humans, pets (dogs and cats), and wild animals (birds, mammals). Understanding these interactions, specifically the role that alternative competent hosts play in the transmission of disease, can improve the management strategies used to monitor and manage it.

Lyme disease is caused by the bacteria Borrelia burgdorferi, which is a complement-resistant spirochete capable of varying its gene expression to adapt physiologically to a variety of host environments (Burgdorfer et al., 1982; Tilly et al., 2008; CDC, 2016). The specific strain that causes infection in animals and humans in the United States is B. burgdorferi sensu stricto (Bacon et al., 2008). However, other species, Borrelia burgdorferi sensu lato, infect humans in other parts of the world, particularly in the Northern hemisphere (Comstedt et al., 2006; Poupon et al., 2006). In the United States, Borrelia burgdorferi is expanding its range, and the prevalence of Borrelai burgdorferi bacteria in ticks has increased rapidly throughout the northeastern region over the past three decades (Kurtenbach et al., 2006; Bacon et al., 2008; CDC, 2016). In 2015 in the United States, 95\% of confirmed Lyme disease cases were reported from 14 states, 12 of 
which are in the northeast (CDC, 2016). These states include Connecticut, Delaware, Maine, Maryland, Massachusetts, New Hampshire, New Jersey, New York, Pennsylvania, Rhode Island, Vermont, and Virginia (CDC, 2016). Much of this expansion can be attributed to the generalist nature of this bacterium, because it can infect and be carried by a variety of different host species including small mammals, reptiles, and birds (Kurtenbach et al., 2006). Some of these species are also competent reservoirs for Borrelia burgdorferi, meaning they play a vital role in the enzootic cycle of Lyme disease by storing and transporting the bacteria to be spread through subsequent feedings by vectors (Anderson and Magnarelli, 1984; Anderson et al., 1986; Levi et al., 2016).

The reservoir competent hosts in the Northeastern United States, referred to as carriers, include the White-footed mouse (Peromyscus leucopus), Eastern chipmunk (Tamias striatus), and a variety of songbird species including the Northern cardinal (Cardinalis cardinalis), American robin (Turdus migratorius), Carolina wren (Thryothorus ludovicianu), Song sparrow (Melospiza melodia), Ovenbird (Seiurus aurocapillus), Veery (Catharus fuscescens), and Gray catbird (Dumetella carolinensis) (LoGuidice et al., 2003; Giardina et al., 2010). These carriers cannot transmit the disease directly to another animal, however, they can carry the diseasecausing bacteria in their blood without suffering from the negative effects of the disease (Giardina et al., 2000; Ginsberg et al., 2005; Levi et al., 2016). The bacteria can then be spread to other host species through subsequent feedings by tick vectors.

The tick species Ixodes scapularis, commonly referred to as the black-legged tick, is the primary vector of Lyme disease in the Northeastern United States (Bacon et al., 2008; CDC, 2016). Ixodes scapularis is a three-host tick, meaning each postembryonic life stage (larva, nymph, and adult) needs a single blood meal to molt into the next stage (Sonenshine, 1991). The complete life cycle for Ixodes scapularis requires approximately 2 years (CDC, 2016). Ticks can maintain Borrelia burgdorferi in their midgut through successive molts, so once a tick is infected it can remain infected (and capable of infecting other species) throughout its entire life cycle (Giardina et al., 2000). The bacteria rests in the midgut of the tick and is transferred to the salivary glands where it can be secreted through their saliva when they bite a host (Tilly et al., 2008). Tick saliva also has immunosuppressive properties that increase the host's susceptibility to infection (Mannelli et al., 1994). Ticks can feed on up to 3 hosts per life stage, potentially encountering 9 different hosts throughout one tick's complete life cycle (Randolph, 1998). Ixodes scapularis ticks feed on a variety of hosts depending on their life stage. Larva and nymphs typically feed on small mammals, reptiles, and birds, and nymphs are also the life stage that is most likely to feed on humans (Burgdorfer and Gage, 1986; Tilly et al., 2008; CDC, 2016). Adult Ixodes scapularis ticks primarily feed on larger mammals including humans (Burgdorfer and Gage, 1986). Although all life stages of Ixodes scapularis ticks will feed on humans, they are typically incidental hosts and are not specifically targeted by the ticks like other large mammals (Anderson, 1989).

Peak activity and feeding for Ixodes scapularis ticks is dependent upon their life stage. Peak feeding time for larva is mid-to-late summer (July-August), whereas nymphs are most active in the spring and early summer (March-July) and adults feed primarily in the fall and early spring (September-March) (CDC, 2016). The asynchronous seasonality of feeding times between the larval and nymphal stage ticks in the Northeastern United States leads to a high prevalence of infected questing nymphs and an efficient transmission cycle for tick-borne diseases like Lyme disease (Wilson and Spielman, 1985). Infected nymphs that are active in the spring and early summer can transmit bacteria to small reservoir competent vertebrate hosts, which will carry the 
bacterium (Yuval and Spielman, 1990). Then, uninfected larva that feed in late summer are able to acquire the bacterium from these infected small vertebrates and maintain the infection throughout their molt, resulting in a new population of infected nymphs in the spring (Yuval and Spielman, 1990). The larval and nymphal feedings are the most crucial to maintaining the disease cycle because Borrelia burgdorferi spirochetes are not transmitted trans-ovarially from parent to offspring (Burgdorfer, 1989). The nymphal stage is also the stage that is most likely to infect humans due to their small size which makes them difficult to detect and remove before the disease is transmitted (Tilly et al., 2008).

Both abiotic and biotic factors affect the prevalence and establishment of tick populations in a community (Gray, 2002). The major abiotic factor affecting tick populations is climate, which affects the survival and reproductive rates of the vectors, their distribution and abundance, and the intensity and temporal pattern of feeding activity (Gray, 2002; Kovats et al., 2001; Ogden et al., 2005; Loss et al., 2016). The sustained global warming rate of +0.2 degrees Celsius per year since the 1970s is considered rapid climate change, which is difficult for ecosystems and species to adapt to (Kovats et al., 2001). Climate has the largest impact on tick survival during non-parasitic periods of the life cycle (breeding and molting) due to their inability to survive temperatures or rainfall outside of a specific range (Ogden et al., 2004). Increasing temperatures and variation in rainfall results in an expansion in the range of suitable habitats for ticks in the United States (Harvell et al., 2002; Ogden et al., 2008; Hamer et al., 2011). Interstadial development rates of Ixodes scapularis are mainly controlled by ambient temperature in northeastern North America, where the rate at which ticks develop into the next life stage increases nonlinearly as temperature increases (Ogden et al., 2004). Diapause phenomena, like delayed development or host-seeking activity, also affect development rates and could be attributed to climate changes (Ogden et al., 2004). Although climate is an abiotic factor, it affects many biotic factors, like vegetation growth and habitat suitability, that influence tick survivability and expansion (Brinkerhoff et al., 2009). Another biotic factor affecting tick populations is host density (Gray, 2002). As long as the hosts are vulnerable to infestation by each life stage of the tick, an increase in host density results in increased tick population maintenance and establishment in an area (Gray, 2002). Host density is typically favorable for Ixodes scapularis ticks because they are generalists, meaning they feed on a large variety of hosts, including small and large mammals, birds, and reptiles (Kurtenbach et al., 2006; Hamer et al., 2011).

The generalist nature of both the causative agent of Lyme disease (Borrelia burgdorferi) and its primary vector (Ixodes scapularis) explains why Lyme disease is able to spread so effectively via transmission amongst different host species. Contemporary research about tick-host-disease interaction focuses on the role that mammals, like the White-footed mouse, Eastern chipmunk, and the White-tailed deer (Odocoileus virginianus), play in the spread of Lyme disease (LoGuidice et al., 2003; Ginsberg et al., 2005; Levi et al., 2016). However, deer are incompetent reservoirs for the bacterium because their blood contains borreliacidal agents that halt the spread of the bacteria (Telford et al., 1988). Also, although the White-footed mouse and Eastern chipmunk are described as some of the most competent reservoir hosts for Borrelia burgdorferi, they are limited in their ability to spread the bacterium due to the relatively small distance that these species travel (LoGuidice et al., 2003). The White-footed mouse is capable of storing and spreading Borrelia burgdorferi for up to 13 months, however, their home range only spans 2.5 acres on average (Stickel, 1968; Donahue et al., 1987). These mammalian limitations in ability to 
transmit or disperse the pathogen or vector indicate the need for further research on the role that alternative, more efficient carriers may play in the transmission of this disease.

Disease ecology research focuses on the role that vectors, hosts, and carriers have in the transmission of Lyme disease within the environment. Lyme disease involves the interaction between at least three species (the host, pathogen, and vector) (Keesing et al., 2006). Therefore, identifying the role that species diversity plays in disease transmission is crucial for understanding the maintenance of Lyme disease in the environment. The "Dilution Effect" states that increasing host diversity in the community can decrease the prevalence of infection in the ticks that inhabit that community (LoGuidice et al., 2003). This concept states that increasing the variety and number of host species in the community could provide exposure to less reservoir competent hosts, which would then dilute the presence of the disease in the host community (LoGuidice et al., 2003; Levi et al., 2016). Increasing the host species diversity of a community, particularly with non-competent reservoirs for the bacteria, can dilute the prevalence of the disease and decrease the nymphal infection prevalence (NIP) in that community (Giardina et al., 2000; LoGuidice et al., 2003; Levi et al., 2016). This NIP value not only reflects the state of nymphal infection of animals within a specified area, but also the area-specific risk of human exposure, because nymphs are the stage most likely to infect humans (Barbour and Fish, 1993).

A major point of consideration for NIP is the potential additive effect risk, whereby introducing more potential host animals can result in increased access to more reservoir competent hosts for the ticks (Levi et al., 2016). However, high host diversity is more likely to decrease disease risk than increase it, especially when pathogen transmission is frequencydependent, the most competent hosts are widespread and abundant, and transmission is greater within species than between them (Keesing et al., 2006). During years when chipmunk density was high, tick burdens on mice were low, indicating that the presence of an alternative host for the ticks reduced the interactions between ticks and White-footed mice, the most competent reservoir for Borrelia burgdorferi (Keesing et al., 2006). Some proposed mechanisms for the dilution effect are encounter reduction, transmission reduction, susceptible host regulation, infected host mortality, recovery augmentation and vector regulation (Ostfeld, 2011). For tickborne diseases, encounter reduction, host regulation, and vector regulation are the three most likely mechanisms (Ostfeld, 2011).

Determining the roles that alternative carriers could play in tick-borne disease transmission, vector range expansion, and maintenance of the pathogen is crucial to understanding and controlling the spread of Lyme disease (Ogden et al., 2006; Bradley and Altizer, 2007; Levi et al., 2016). Songbirds, for instance, have acted as very efficient carriers of disease, including West Nile and H5N1 Avian Influenza (Rappole and Hubálek, 2003; Kilpatrick et al., 2006). Based on their vulnerability to infestation by ticks, effectiveness as reservoirs for the bacteria, and ability to travel long distances over short periods of time, songbirds have the potential to be very effective carriers and dispersers of Lyme disease. Songbirds play a major role in the range expansion of both Borrelia burgdorferi and Ixodes scapularis and in the maintenance of Borrelia burgdorferi in the absence of its purported vector species (Ogden et al., 2008; Dubska et al., 2009; Elias et al., 2010; Hamer et al., 2011). Ground-dwelling songbirds are vulnerable to infestation by ticks in the nymphal stage, and Ixodes scapularis is commonly found on birds (Rand et al., 1998; Giardina et al., 2000; Ginsberg et al., 2005; Comstedt et al., 2006). Nonmigratory ground foraging species are the most likely to have high prevalence of tick infestation and carry Borrelia burgdorferi-infected ticks. Some species, including thrushes 
(Turdidae), sparrows (Paserellidae), and many wood warblers (Parulidae), are super-carriers that are especially likely to carry ticks (Loss, 2016).

To date, the tick infestation rates reported on birds throughout the United States are low, typically $<6.0 \%$. On Appledore Island in Maine (a well-established bird migration stopover site), $>36,000$ fall migrants examined from 1990-2008 showed a tick infestation rate for birds of 0.7\%, and $71.0 \%$ of the ticks were identified as Ixodes scapularis (Elias et al., 2010). The other species of the ticks collected in this study were Dermacentor variabilis, Ixodes dentatus, Ixodes muris, Ixodes brunneus, Amblyomma americanum, and Haemaphysalis leporispalustris (Elias et al., 2010).This same study performed in the spring examined $>49,000$ birds and resulted in a $2.6 \%$ infestation rate, with $98.0 \%$ of the ticks collected identified as Ixodes scapularis (Elias et al., 2010). In the Midwestern United States (IL) >6,000 fall migrants examined from 2005-2010 resulted in an infestation rate of $1.6 \%$, with only $8.0 \%$ of these hosted ticks identified as Ixodes scapularis (Hamer et al., 2012). The other species of the ticks collected in this study were Dermacentor variabilis, Ixodes texanus, Ixodes cookei, Ixodes dentatus, Ixodes marxi, and Haemaphysalis leporispalustris (Hamer et al., 2012). More recently in Texas, nearly 4,000 birds were examined, of which $3.6 \%$ were infested by ticks and only $0.02 \%$ were Ixodes scapularis (Cohen et al., 2015). The spatial variation in Ixodes scapularis infestation prevalence and representation between the Northeastern United States and other regions is expected in part because Illinois and Texas are both outside of the known geographic range of Ixodes scapularis (CDC, 2016). However, these findings further support the fact that Ixodes scapularis could be expanding its range. The small infestation rates found in each of these studies (Maine - $0.7 \%$, $2.6 \%$; Illinois $-1.6 \%$; Texas $-3.6 \%$ ) could be attributed to a variety of factors, including the species of birds examined, the effort put into searching the birds for ticks, or the species diversity of alternative carriers in the ecosystems where these studies where performed (Ogden et al., 2008; Loss et al., 2016).

Although many studies showed relatively low infestation percentages, a study that sampled birds in the northeastern states of Connecticut, Massachusetts, Rhode Island, Maryland, New Jersey, New York, Pennsylvania, and Virginia found that $23.5 \%$ of 2,871 birds that were examined and searched thoroughly were infested with ticks, of which $67.7 \%$ were carrying at least one immature Ixodes scapularis tick (Brinkerhoff et al., 2010). In Lyme, CT from 1989 1991, 803 out of 5,297 (15.2\%) birds examined were infested with ticks, from which 4,065 ticks were collected and 94,0\% of the ticks were Ixodes scapularis (Stafford, 1995). Many songbirds were highly infested by Ixodes scapularis, including Ovenbirds (44.4\% of 286), Common yellowthroats (Geothlypis trichas) (27.1\% of 188), Hooded warblers (Setophaga citrina) (35.0\% of 80), Carolina wrens (50.9\% of 110), House wrens (Troglodytes aedon) (21.6\% of 102), Wood thrushes (Hylocichla mustelina) (23.0\% of 867), Veeries (32.5\% of 246), and American robins (36.2\% of 69) (Stafford et al., 1995). Of the 5,297 birds examined, 803 birds (15.2\%) of 36 different species were infested with ticks (Stafford et al., 1995). In New York in 1986, 28.0\% of 301 birds examined were infested with ticks (Battaly et al., 1987). Over the course of 7 years (1989-1996) in Maine, 1,972 birds were examined and the infestation rate increased from 40.0$60.0 \%$ over the course of the study (Rand et al., 1998).

Songbirds were originally thought to have hindered the spread of Lyme disease due to ticks choosing to feed on birds instead of more reservoir competent species, like the White-footed 
mouse (Hamer et al., 2011; Levi et al., 2016). However, research revealed that songbirds are effective reservoirs for Lyme disease and could be important for the geographic range expansion of the disease. Many songbirds can harbor Borrelia burgdorferi in their blood, for up to 2 months or more in some species (Giardina et al., 2000; Richter et al., 2000; Ginsberg et al., 2005; Levi et al., 2016). Borrelia burgdorferi spirochetes were recovered from the blood of one Northern mockingbird, one Gray catbird, two Prairie warblers, one Orchard oriole, one Common yellowthroat, and one American robin, proving that at least some avian species are spirochetemic and capable of harboring the bacteria and transporting it to new geographic areas (Anderson and Magnarelli, 1984). In a laboratory study which placed Ixodes scapularis larva on American robins and Song sparrows infected with Borrelia burgdorferi, $81.8 \%$ of larvae placed on American robins and $21.1 \%$ of larvae placed on song sparrows subsequently became infected by feeding on the experimentally infected birds (Ginsberg et al., 2005). Some additional reservoir competent species supported by literature include the Northern cardinal, Carolina wren, Ovenbird, and Veery (Anderson et al., 1986; Giardina et al., 2000; Ginsberg et al., 2005; Richter et al., 2000). In a non-endemic area in the Midwest, Ixodes scapularis infestation in songbirds was $1.0 \%$, however, the prevalence of Borrelia burgdorferi in 29 blood samples taken from migratory songbirds was $31.0 \%$ (Schneider et al., 2015). This high prevalence of Borrelia burgdorferi found in songbirds in an area where it is not regularly found indicates that songbirds contribute to the spread of both Ixodes scapularis ticks and Borrelia burgdorferi bacteria, either independently or at the same time. Therefore, it is imperative that the factors affecting tick infestation and disease prevalence in songbirds are studied further to better understand how and why they are becoming infested and what impacts it may have on human risk of exposure to the disease.

Some of the reservoir competent songbirds that are non-resident species migrate anywhere from a few hundred to several thousand kilometers over the course of their spring and fall migrations between their breeding and wintering grounds (DeLuca et al., 2015). Many of these migratory songbirds pass through the northeastern United States (in Borrelia burgdorferi's range) in the spring and fall when nymphal Ixodes scapularis are actively questing, increasing the likelihood of infestation by an infected tick (Scott et al., 2001). Warblers, like the Common yellowthroat, can travel from northern Canada to Central America over the course of a few weeks during migration (Guzy and Ritchison, 1999). Thrushes, like the wood thrush, travel from southern Canada to Central America during migration, crossing the Gulf of Mexico $(1,000 \mathrm{~km}$ of open water) in approximately 28 hours (Deppe et al., 2015). The ability of many songbird species to travel long distances over short periods of time makes them very effective dispersers of both the diseases that they carry and the ticks that feed on them. The average distance traveled by an infested migratory bird carrying a larval Ixodes scapularis tick is approximately 340 kilometers over the course of 4 days (Ogden et al., 2008). Furthermore, because many migratory songbirds take breaks at stopover sites during these long journeys, there are many places in between the breeding and wintering grounds that are vulnerbable to introduction of Ixodes scapularis ticks, Borrelia burgdorferi, or both based on the amount of time that the birds spend at these sites refueling to complete the migration (Elias et al., 2010). Lyme disease may instead be spreading slowly over short distances via avian migration rather than expanding rapidly over large distances. Many birds that are competent reservoirs are expanding their ranges as well, meaning they are capable of introducing Borrelia burgdorferi and Ixodes scapularis in these new locations, further expanding the range of the disease (Beddall, 1963). Northern margins of breeding ranges for some North American songbird species have been shifting northward over 
recent decades due to seasonal variations in climate (Hitch anad Leberg, 2007; Coristine and Kerr, 2015).

The emergence of infectious diseases in humans is affected by both environmental factors, like climate change, altering the spatial distribution and abundance of infectious agents and their hosts and by demographic factors that affect the likelihood of human exposure to these sources of infection (Vanwambeke et al., 2010). Increases in human exposure to Lyme disease can be attributed to a variety factors, including; human expansion into forested areas that increases exposure to ticks and hosts, seasonal climate changes that increase both the duration of time that ticks spend feeding and that humans spend outside, and increased prevalence of both the vector and host species (Gray, 2002; Ogden et al., 2006; Bradley and Altizer, 2007; Hamer et al., 2012; CDC, 2016)

The majority of reported human cases of Lyme disease in the Northeastern and Northcentral United States occur in suburban and rural communities that border or intersect with forest ecosystems where hosts, vectors, and pathogens are found (Bacon et al., 2008; Tran and Waller, 2013). The proximity of some of these human populated communities to forested areas that are home to many of the hosts of Ixodes scapularis nymphs at least partially explains the increased prevalence and expansion of Lyme disease (Frank et al, 1998). Habitat fragmentation that occurs as a result of human expansion into forested areas can lead to reduced biodiversity that can alter the species balance in an ecosystem through isolation of low mobility species (Sutherst, 2004). Decreased biodiversity also decreases the dilution effect for vector-borne diseases, resulting in increased infection rates of larval and nymphal ticks in an area due to the presence of a high concentration of competent hosts for them to feed on (Sutherst, 2004). This increase in NIP is of particular concern for humans because nymphs are the life stage most effectively able to transmit the disease to humans (Barbour and Fish, 1993). Lack of certainty about how individual ecosystems respond to deforestation and habitat fragmentation is another major concern because changes in the physical environment can completely alter the patterns of a disease, making it difficult to monitor and control (Sutherst, 2004).

The complex zoonotic cycle of Lyme disease involves multiple hosts, vectors, reservoirs, and the influence of various environmental factors, making it difficult for public health professionals, veterinary specialists, or environmentalists to monitor and manage it independently. However, the involvement of humans, animals, and the environment in this disease cycle creates an opportunity for collaboration and communication between experts in the fields of public health, veterinary medicine, and environmental health to find a solution to this problem. As the pathogen and primary vector of Lyme disease continue to expand their range and infect more people and animals, it is vital that we understand what factors are affecting this expansion in order to slow or stop it. Therefore, understanding the role that alternative hosts, like songbirds, play in the spread of tick vectors and the bacterial pathogen Borrelia burgdorferi is critical. 


\section{STATEMENT OF THE PROBLEM}

Zoonotic diseases are a primary concern in the fields of human, veterinary, and environmental health due to the large number of organisms that are susceptible to them. Lyme disease is a vector-borne disease caused by the bacteria Borrelia burgdorferi, which has been shown to infect humans, companion animals, and wildlife (small and large mammals, reptiles, and birds). Although Lyme disease relies on the arthropod vector Ixodes scapularis (blacklegged tick) to infect its hosts and spread the bacteria in the Northeastern United States, many different species, including birds and small mammals, are involved in the complex zoonotic cycle of the disease. Many of these species act as carriers that are unable to spread the disease themselves, however, they can carry infected ticks and can sometimes even store the diseasecausing bacteria in their blood. This can lead to transmission of the disease through subsequent feedings on the carriers by additional ticks. From a dispersal perspective, songbirds have the potential to act as effective carriers because of their exposure to Ixodes scapularis ticks, reservoir competency for the Borrelia burgdorferi bacteria, and the large distances that they travel in relatively short periods of time during migration.

In choosing our study sites, we took into account the prevalence of Lyme disease, the ranges of Borrelia burgdorferi and Ixodes scapularis, and the migratory paths of songbirds in order to encompass all of the components of this disease and its transmission. New York and Pennsylvania were chosen because they are in the top five states for Lyme disease prevalence, and West Virginia was chosen because it has recently become endemic and borders PA. All three of these states are also included in the ranges of Ixodes scapularis and Borrelia burgdorferi.

Many studies have looked at the reservoir competency of certain songbird species in laboratory settings and found that some species of songbirds are competent reservoirs for Borrelia burgdorferi. However, very few have collected blood from birds in the wild to better understand the enzootic cycle of this disease and the reservoir competency of these species in nature. We chose to collect and test blood from both tick infested and non-infested birds that we captured to look at the prevalence of Borrelia burgdorferi within these songbird populations rather than just on the ticks that they carry. This is especially important because some species, like the American robin, have shown the ability to store the bacteria in their blood for up to 2 months. Testing ticks removed from birds and the blood from infested and non-infested birds is necessary to determine the prevalence of Lyme disease in these areas at the time of capture and to better understand the potential that these birds have as dispersers of the ticks and bacteria.

Studies have also measured the tick infestation rate in songbirds, however, most of these studies found low infestation rates $(<6 \%)$. One potential problem with these studies is that they included all songbird species that were captured rather than just looking at those species known to be susceptible to ticks. This could greatly underestimate the involvement of birds in the spread of the disease, for many songbirds, like those found in the canopy, may never come into contact with a tick. We chose to target 14 focal species that are known ground-dwelling species and have documented tick infestation in the literature to more accurately depict the role of birds in the transmission cycle of this tick-borne disease.

Traditional studies looking at the transmission and dispersal of Lyme disease have focused on small mammals as the primary carriers of the disease. However, with the rapid rate of range expansion documented in both Ixodes scapularis and Borrelia burgdorferi, it is necessary to consider the potential role that alternative carrier species, like songbirds, may have in the dispersal of Lyme disease. 


\section{CHAPTER 1: FACTORS AFFECTING TICK INFESTATION OF SONGBIRDS IN THE NORTHEASTERN UNITED STATES}

\section{Introduction}

In North America, tick-borne diseases are the most common type of vector-borne zoonotic disease impacting humans (CDC, 2016). Most contemporary research on tick-hostdisease interaction in the United States focuses on the mammalian role as hosts, however, the effectiveness of these mammals as dispersers of ticks and the diseases that they carry is limited by factors like reservoir incompetency, small home and migratory ranges, and short lifespans (Telford et al., 1988; LoGuidice et al., 2003; Ginsberg et al., 2005; Brinkerhoff et al., 2011; Levi, 2016) Determining the roles that alternative hosts play in tick-borne disease transmission is crucial to understanding and controlling the spread of vector-borne diseases (Ogden et al., 2006; Bradley and Altizer, 2007; Levi et al., 2016).

Passerines (songbirds) play a significant role in the enzootic cycles of zoonotic diseases by acting as large scale dispersers of vectors and the pathogens that they carry (Rappole and Hubálek, 2003; Ogden et al., 2008; Dubska et al., 2009; Elias et al., 2010). Acting as both reservoirs for pathogens and carriers of vectors, songbirds are involved in the introduction of new vector species in previously uninhabited areas and also the maintenance of vector populations as hosts for local transmission (Rappole and Hubálek, 2003; Ogden, et al. 2008; Loss et al., 2016; De Oliveira et al., 2018). By focusing on infestation rates of ticks on birds, it is possible to gain insight into the distribution of these pathogens and their potential for spreading novel vector and disease species (Stafford et al., 1995; Rand et al., 1998; Elias et al., 2010; Brinkerhoff et al., 2010, 2011; Hamer et al., 2012; Cohen et al., 2015; Schneider et al., 2015).

Migratory songbirds are among the most studied species for understanding the longdistance dispersal of zoonotic diseases (Hubálek, 2004; Ogden et al., 2008). Travel distances of migratory songbirds are variable, ranging anywhere from a few hundred to several thousand kilometers during spring and fall migrations, stopping at various sites between their wintering and breeding grounds where ticks could attach to or fall off of them (Ogden et al., 2008; DeLuca et al., 2015). Veeries can travel up to 259.1 kilometers in a single night (Cornell Lab of Ornithology, 2014). Non-migratory or resident species are also involved in the disease cycle because they contribute to the maintenance of the disease by acting as hosts for ticks.

In the northeastern United States Lyme disease is the prominent tick-borne disease, which is transmitted by Ixodes ticks, specifically Ixodes scapularis. Ixodes scapularis has been documented on $>70$ species of North American songbirds. Spring bird migration (April-June) in the United States corresponds temporally with high nymphal Ixodes scapularis questing activity, which increases the likelihood of bird infestation by questing ticks during this migration period (Scott et al., 2001; Brinkerhoff et al., 2009, Gatewood et al., 2009). Fall migration (AugustOctober) corresponds with the beginning of the larval stage in ticks, when larva have just hatched and are beginning to quest for their first meal (Gatewood et al., 2009). This also corresponds with the beginning of the transition from the nymphal stage into adulthood, when finding a blood meal is vital to reproduction (Gatewood et al., 2009).

There is significant geographic variation in tick infestation rates on birds throughout the United States, despite studies being conducted over a similar time period. In the highly Lyme endemic northeastern United States, many studies reported unexpectedly low infestation rates 
$(<6 \%)$ in birds (Elias et al., 2010; Hamer et al., 2012; Cohen et al., 2015). Other studies, however, documented significantly higher infestation rates (between 15-28\%) in similar regions (Battaly et al., 1987; Stafford et al., 1995; Brinkerhoff et al., 2010). Variation in infestation rates could be attributed to a variety of factors, including the foraging habits of the bird species included for research, the protocols used for searching the birds for ticks, or the species diversity of alternative carriers in the ecosystems where these studies were performed (Ogden et al., 2008; Loss et al., 2016;). Regardless of the reason, this variation in infestation rates leads to uncertainty about the role that birds play in the enzootic cycle of tick-borne diseases.

The goal of this study was to document tick infestation of 14 species (Table 1-1) of ground-dwelling songbirds in Pennsylvania, New York, and West Virginia during spring and fall migration of 2017. These 14 species were chosen based on their likelihood of exposure to ticks, likelihood of capture, and their migratory range. The objectives are to determine what bird characteristics (sex, age, mass, wing length, fat score, season, location, phylogenetic family, migratory strategy) are associated with (1) likelihood of infestation or (2) size of tick load on birds. Infestation is defined as having one or more ticks at the time of examination, and tick load describes the number of ticks removed from the bird at the time of examination. I hypothesize that females will be more likely to be infested and have larger tick loads than males because males spend more time preening than females, especially in the spring when they are trying to attract a mate (Zolnierowicz et al., 2016). I also expect younger birds to be more infested and have higher tick loads than older birds because older birds have greater experience with preening and maintaining their health (Anders et al., 1998; Bush and Clayton, 2018). I predict that lighter birds will be more infested and have higher tick loads than heavier birds and birds with a lower fat score will be more infested and have a higher tick load than those with a higher fat score based on the energy available for preening (Brown et al., 1995). I believe that NY will have a higher infestation rate and larger tick loads than PA and WV based on the documented tick presence within each state, and that birds examined in the spring will be more infested and have higher tick loads than those in the fall due to the temporal component of the life cycle of the ticks that are parasitizing them (Gatewood et al., 2009; CDC, 2016;). Lastly, I hypothesize that members of the phylogenetic family Turdidae (Thrushes) will be infested by the fewest number of ticks because of their long beaks, which would increase their ability to preen for parasites (Clayton et al., 2005).

\section{Methods}

\section{Study Area}

Birds were searched for ticks in PA, NY, and WV based on the presence of Ixodes scapularis and prevalence of Lyme disease in these areas (CDC, 2016). Within each state, partnerships were established with bird banding stations whom had ongoing mist-netting operations.

Powdermill Avian Research Center (PARC) is located on a 10-ha plot of fields, hedgerows, and marshy ponds with alder (Alnus glutinosa) and willow (Salix bebbiana)-lined streams in Stahlstown, PA. The elevation is 411.5 kilometers (1,350 feet) above sea level, and the research area is bordered by deciduous forest to the east with low-intensity agricultural fields of corn (Zea mays) in the Ligonier Valley to the west. Forests are primarily comprised of maple maple (Acer saccharum), oak (Quercus robur), and hickory (Carya ovata) trees. Average temperature during spring migration (mid-April to June) ranges from a high of $16.67^{\circ}-26.67^{\circ} \mathrm{C}$ to a low of $1.67^{\circ}-$ $11.11^{\circ} \mathrm{C}$ with an average rainfall of $10.41-11.18 \mathrm{~cm}$ (Young, 2017). During fall migration (mid- 


\begin{tabular}{|c|c|c|c|}
\hline Common Name & Scientific Name & Family & Migratory Strategy \\
\hline Northern Cardinal & Cardinalis cardinalis & Cardinalidae & R \\
\hline Song Sparrow & Melospiza melodia & Emberizidae & R \\
\hline Brown Thrasher & Toxostoma rufum & Mimidae & SM \\
\hline Gray Catbird & Dumetella carolinensis & Mimidae & SM \\
\hline Common Yellowthroat & Geothlypis trichas & Parulidae & LM \\
\hline Hooded Warbler & Setophaga citrina & Parulidae & SM \\
\hline Ovenbird & Seiurus aurocapillus & Parulidae & LM \\
\hline Carolina Wren & Thryothorus ludovicianus & Troglodytidae & R \\
\hline House Wren & Troglodytes aedon & Troglodytidae & SM \\
\hline American Robin & Turdus migratorius & Turdidae & SM \\
\hline Hermit Thrush & Catharus guttatus & Turdidae & SM \\
\hline Swainson's Thrush & Catharus ustulatus & Turdidae & LM \\
\hline Veery & Catharus fuscescens & Turdidae & LM \\
\hline Wood Thrush & Hylocichla mustelina & Turdidae & LM \\
\hline
\end{tabular}

Table 1-1. Information on 14 focal species. Details about the 14 species being examined including the common name, scientific name, family, and migratory strategy. $* \mathrm{R}=$ resident, $\mathrm{SM}=$ short-distance migrant, $\mathrm{LM}=$ long-distance migrant 
August to October), average temperatures range from a high of $16.67^{\circ}-28.89^{\circ} \mathrm{C}$ and a low of $2.22^{\circ}-13.33^{\circ} \mathrm{C}$ with an average rainfall of $8.13-10.67 \mathrm{~cm}$ (Young et al., 2017).

Braddock Bay Bird Observatory (BBBO) in Rochester, NY is located along the nearshore habitats on the south shore of Lake Ontario at an elevation of around 91.4 kilometers (300 feet) above sea level. The lake functions as a barrier to migration, therefore, many birds are captured at the station between migratory flights to rest and recover. The habitat is primarily early successional deciduous forest consisting mainly of sugar and red maple (Acer rubrum), red oak (Quercus rubra), hemlock (Tsuga maculatum), and American beech (Fagus grandifolia) trees with patchy shrubs (Smith et al., 2015; Widman, 2016). It is surrounded by abandoned agricultural fields and state-managed land (Smith et al., 2015). Average temperatures during spring migration range from a high of $13.33^{\circ}-25.00^{\circ} \mathrm{C}$ to a low of $2.22^{\circ}-13.33^{\circ} \mathrm{C}$ with an average rainfall of 7.11-8.64 cm (Young et al., 2017).

The Allegheny Front Migration Observatory (AFMO) in Dolly Sods, WV is located on the high ridge of Allegheny Front Mountain in the Monongahela National Forest. This area is known for its high elevation meadows and cranberry bogs (Vaccinium macrocarpon). The elevation is around 1,219.2 kilometers (4,000 feet) above sea level, and this rocky plateau is dominated by red spruce trees (Picea rubens) and second-growth forest, including aspen (Poppulus tremuloides) mountain ash (Sorbus Americana), huckleberry (Vaccinium membranaceum), and blueberry bushes (Vaccinium corymbosum). The average temperature during fall migration ranges from a high of $15.00^{\circ}-23.89^{\circ} \mathrm{C}$ to a low of $1.11^{\circ}-10.00^{\circ} \mathrm{C}$ with an average rainfall of 8.89 $11.94 \mathrm{~cm}$ (Young et al., 2017).

The PARC, BBBO, and AFMO are located along the western Atlantic flyway for migratory songbirds. Birds were examined during spring migration of 2017 at the BBBO in NY, during fall migration of 2017 at AFMO in WV, and during both the spring and fall migrations of 2017 at the PARC in PA.

\section{Bird Capture and Examination}

During the spring and fall migrations of 2017, a random sample of birds that were mistnetted at each station were examined for ticks. During spring migration of 2017, birds were examined at PARC for 3 days at the beginning (4/26-4/28) and 3 days at the end of spring (5/165/18). At BBBO, birds were examined for 3 days in early May (5/11-5/13) and for 3 days in late May (5/22-5/24). During the Fall migration of 2017, birds were examined at PARC over the course of one 3-day sampling period in mid-September (9/14-9/16), and at AFMO during 2 separate 2-day sampling periods in early September (9/3-9/4) and late September (9/23-9/24). Birds were also searched opportunistically by lead banders at the banding stations in PA $(5 / 3$, $5 / 21,5 / 23,5 / 27,5 / 28,5 / 31)$ and NY $(5 / 16,5 / 18,5 / 19,5 / 20,5 / 21)$ in the spring, and in WV $(9 / 8$, $9 / 9,9 / 16,9 / 17)$ in the fall.

In conjunction with existing banding operations at each station, examined birds were captured using $30 \mathrm{~mm}$ mesh mist nets that were set up at sunrise and left open for 6 hours. There were 70 nets open at the PARC, 32 at BBBO, and 45 at AFMO. The nets were checked for birds every 30 minutes, and birds were transported from the nets back to the banding station in cloth or paper collection bags. Upon capture and removal from the collection bag, each bird was banded, identified to species, and sexed. At the PARC and BBBO, each bird was also given a fat score (0-5), weighed (g), and had their wing length measured (mm) (Pyle, 1997). 


\section{Tick Infestation and Tick Load}

After processing by lead banders, the 14 focal species were searched for ticks and blood samples were collected from a random sample of these birds. All bird handling, tick collection, and blood draw was done under West Virginia University IACUC \#1704005815 and USFWS Federal Permit \#08231. A total of 13 species were examined during the spring sampling, and 1 species was added for the fall sampling (Swainson's thrush) because it is a common grounddwelling fall migrant captured at each of the collaborating banding stations.

Birds were searched for ticks around the head, neck, ears, eyes, and beak, where ticks are most commonly found on birds (Hamer et al., 2012). The search lasted for approximately 30 seconds for each bird, and all ticks that were found were removed using forceps and stored at room temperature in cryogenic vials filled with $70 \%$ ethanol for 2-6 months before processing (Hamer et al., 2011). Following the tick search, a random sample of infested and non-infested birds were held to have their blood drawn before release as part of another research project. All other birds were released immediately after the tick search was completed.

\section{Data Analysis}

Due to variation in the number of each species examined during both seasons, birds were not separated into individual species for analysis, so the associations between species and infestation or tick load were not assessed. Rather, I chose to group species by family (Thrushes, Mimids, Parulids, and others). Also, data from WV was excluded from the logistic regression and Negative Binomial regression due to the lack of information recorded and the insufficient sample size collected from this state.

The percent of tick infestation was calculated by dividing the number of birds that were infested (at least one tick) by the total number of birds examined. Logistic regression was used to analyze tick infestation probability $(n=311)$ using package lme4 (Bates et al., 2015) in program $\mathrm{R}$. The association between each of the independent variables (sex, age, mass, wing length, fat score, season, state of capture, phylogenetic family, migratory strategy; Table 1-2) and the binary outcome (infested vs. non-infested) was modeled using R (Stokes et al., 2012). Some birds were omitted due to missing data. For individuals with data missing for a single independent variable, the missing value was replaced with the mean value, which was calculated using the values from other individuals of the same species. To determine parameter significance, a global model was run with all of the independent variables. Parameters with the absolute value of the Wald's test statistic ( $\mathrm{z}>1.64)$ were considered significant, which equates to a significant $\alpha<0.1$. The models were re-ran and the parameters were evaluated using the Wald's test statistic. Parameter significance was corroborated by considering parameters to be significant when confidence intervals of parameter estimates did not overlap zero. Lastly, the package AICcmodavg in program $\mathrm{R}$ was used to model comparison with Aikaike's information criterion adjusted for small sample sizes (AICc) (Burnham and Anderson, 2002, Mazzerolle, 2016). The reduced model was considered the top model if $\triangle \mathrm{AICc}<2.0$.

To model factors affecting tick load, the count of the number of ticks found on each bird was modeled. To account for the over dispersion present and based on the large number of 0 's in the data (non-infested or 0 ticks), 3 separate distributions were used; Poisson using package lme4 in program $\mathrm{R}$ (Bates et al., 2015), Negative Binomial (NB; using package MASS in program $\mathrm{R}$ (Venables and Ripley, 2002), and Zero-inflated Poisson (ZIP) using package pscl in program $\mathrm{R}$ 


\begin{tabular}{|c|c|}
\hline Variable & Categories \\
\hline Season & $\begin{array}{c}\text { Spring } \\
\text { Fall }\end{array}$ \\
\hline State & $\begin{array}{c}\text { PA } \\
\text { NY } \\
\end{array}$ \\
\hline $\begin{array}{l}\text { Migratory } \\
\text { Strategy }\end{array}$ & $\begin{array}{c}\mathrm{R}=\text { Resident } \\
\mathrm{SM}=\text { Short-distance migrant } \\
\mathrm{LM}=\text { Long-distance migrant }\end{array}$ \\
\hline Sex & $\begin{array}{c}\mathrm{F}=\text { Female } \\
\mathrm{M}=\text { Male } \\
\mathrm{U}=\text { Unknown }\end{array}$ \\
\hline Age & $\begin{array}{c}\text { HY(Hatch year) = Juvenile } \\
\text { non-HY (After HY, Second Year, After Second Year })=\text { Adults }\end{array}$ \\
\hline $\begin{array}{c}\text { Fat Score } \\
\text { (in } \\
\text { pectoral } \\
\text { space) }\end{array}$ & $\begin{array}{c}0=\text { No visible fat } \\
1=\text { trace of fat } \\
2=\text { space } 1 / 3 \text { filled with fat } \\
3=\text { space } 1 / 2 \text { filled with fat } \\
4=\text { space }>2 / 3 \text { filled with fat } \\
5=\text { space filled with fat }\end{array}$ \\
\hline
\end{tabular}

Table 1-2. Categorical variables. Description of categorical variables being tested for associations with infestation and tick load. 
(Zeileis et al, 2008). In each instance, regression was used to test the association between the continuous variable tick load and each of the independent variables (sex, age, mass, wing length, fat score, season, state of capture, phylogenetic family, migratory strategy; Table 1-2) (Zeileis et al., 2008). To determine parameter significance, we used the same procedure as the logistic regression modeling. Predicted probabilities or predicted tick loads were calculated across the range for significant independent variables while holding the other significant parameters at mean value.

\section{Results}

\section{Bird Capture and Examination}

A total of 371 songbirds of 14 different species were examined during the Spring and Fall migrations of 2017 (Table 1-3). Of these, 190 individuals of 13 different species were examined in the Spring and 181 individuals of 12 species were examined in the Fall. There was a total of 222 birds examined from spring and fall sampling efforts in PA, 109 birds examined from spring sampling efforts in NY, and 40 birds examined from fall sampling efforts in WV. Of the 371 birds examined, Common yellowthroat (33.1\%), Gray catbird (20.8\%), Swainson's thrush (Catharus ustulatus; 14.0\%), and Hooded warbler (7.0\%) were the most frequently examined species (Table 1-3).

\section{Tick Infestation and Tick Load}

A total of 132 birds $(n=371 ; 35.6 \%)$ were infested by 297 nymphs. The average number of ticks per infested bird was $2.25( \pm 0.20)$. There were 131 ticks collected in the Spring and 166 ticks collected in the Fall, with 203 collected in PA, 67 in NY, and 27 in WV. The overall infestation percentage in the spring was $31.6 \%(n=190)$ and in the fall it was $39.2 \%(n=181)$. The birds examined in PA had an infestation of 36.94\% $(n=222)$ in the spring and fall, the birds in NY had an infestation percentage of $33.0 \%$ in the spring $(n=109)$, and the birds in WV had an infestation percentage of $32.5 \%$ in the fall $(n=40)$. The individual with the greatest tick load was a Hooded Warbler from PA, sampled in the fall from which I collected 14 ticks. In the Spring, there were 50 birds infested by at least one tick and no birds were infested by more than 5 , but in the Fall, there were 73 birds infested by at least one tick and 7 birds infested by more than 5 .

In PA and NY, there was an association between probability of infestation and age ( $\mathrm{p}<0.05, \mathrm{z}=3.657$ ), where the infestation probability of juveniles (HY) was $82.2 \%$ greater than adult birds (AHY, SY, ASY) based on logistic regression results (Table 1-4; Figure 1-1). The association between infestation probability and fat score $(\mathrm{p}=0.1075, \mathrm{z}=-1.82)$ was also significant at an alpha level 0.1 (Table 1-4). Individual birds with a fat score of 0 were $73.7 \%$ more likely to be infested than those with a fat score of 4 (Figure 1-1). There was no statistically significant association between infestation probability and the other independent variables based on the models (Table 1-5).

All three tests showed agreement in their results, though the Poisson distribution fit the data least well, therefore I will focus on results from the Negative Binomial and Zero-inflated Poisson analysis. When data from WV and missing data were excluded from the analysis, there 


\begin{tabular}{|c|c|c|c|}
\hline Common Name & Examined & Infested & Ticks Collected \\
\hline American Robin & 1 & 1 & 6 \\
\hline Brown Thrasher & 5 & 3 & 16 \\
\hline Carolina Wren & 5 & 1 & 7 \\
\hline Common Yellowthroat & 123 & 42 & 77 \\
\hline Gray Catbird & 77 & 16 & 25 \\
\hline Hermit Thrush & 3 & 1 & 1 \\
\hline Hooded Warbler & 26 & 11 & 37 \\
\hline House Wren & 8 & 3 & 14 \\
\hline Northern Cardinal & 13 & 4 & 6 \\
\hline Ovenbird & 23 & 11 & 29 \\
\hline Song Sparrow & 17 & 6 & 10 \\
\hline Swainson's Thrush & 52 & 25 & 51 \\
\hline Veery & 6 & 4 & 13 \\
\hline Wood Thrush & 12 & 4 & 5 \\
\hline Total & $\mathbf{3 7 1}$ & $\mathbf{1 3 2}$ & $\mathbf{2 9 7}$ \\
\hline
\end{tabular}

Table 1-3. Infestation results. Summary of samples examined (birds) and collected (ticks) by species in PA, NY, and WV during the spring and fall migrations of 2017

\begin{tabular}{ccccc}
\hline & Estimate & $\mathbf{S E}$ & $\mathbf{z}$ & $\mathbf{P r}>\mathbf{Z}$ \\
\hline (Intercept) & -0.75 & 0.19 & -3.85 & 0.00012 \\
Age & 0.95 & 0.26 & 3.66 & 0.00026 \\
Fat & -0.22 & 0.12 & -1.82 & 0.069 \\
\hline
\end{tabular}

Table 1-4. Logistic regression results for infestation. Significant logistic regression statistics for association between infestation probability and the bird characteristics age and fat score in PA, NY, and WV during the spring and fall migrations of 2017. 


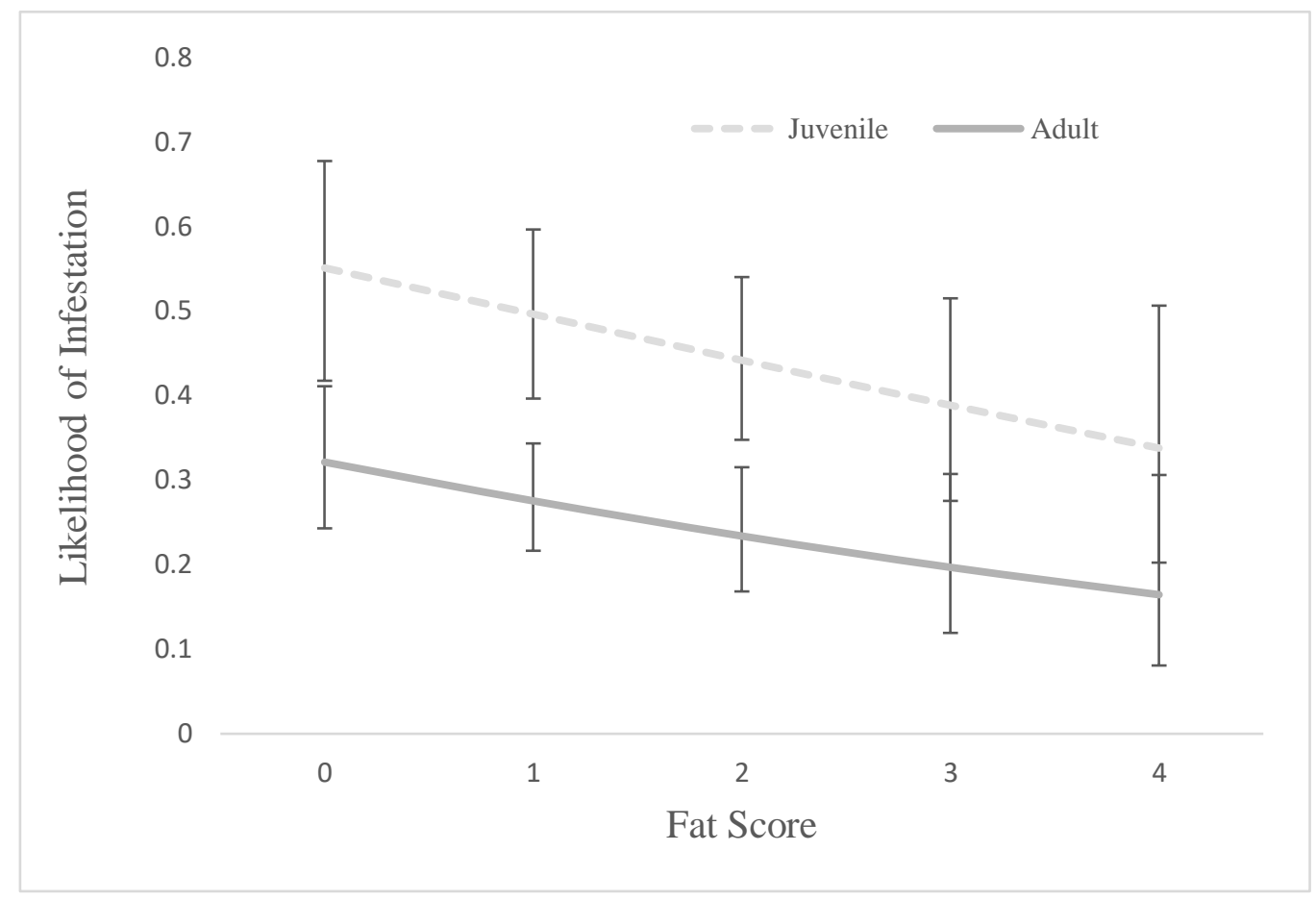

Figure 1-1. Logistic regression results for infestation. Predicted relationship from logistic regression of the association between probability of infestation by age and fat score

\begin{tabular}{cccccc}
\hline Model & AICc & $\Delta$ AICc & AICcWt & Cum.Wt & LL \\
\hline Age+Fat & 391.9 & 0 & 0.39 & 0.39 & -192.93 \\
\hline Age+Fat+Season & 392.7 & 0.76 & 0.27 & 0.66 & -192.29 \\
Age & 393.4 & 1.42 & 0.19 & 0.85 & -194.66 \\
\hline Age*Fat & 393.9 & 1.97 & 0.15 & 1 & -192.89 \\
Constant & 402.4 & 10.45 & 0 & 1 & -200.19 \\
Global & 403.8 & 11.89 & 0 & 1 & -187.2 \\
\hline
\end{tabular}

Table 1-5. Model selection results for infestation. AIC Table reporting on top competitive models of infestation (age+fat, age+fat+season, age, age*fat) in birds examined in PA and NY during the spring and fall migrations of 2017. 
were 213 birds from PA (spring and fall) and 98 birds from NY (spring) included, totaling 311 birds for logistic regression, NB, and ZIP analysis. The overall infestation percentage for the PA and NY birds was $34.41 \%(n=311)$, and they were infested by a total of 243 ticks. The infestation percentage in the spring was $31.58 \%(n=190)$, and for the fall it was $36.36 \%(n=121)$. In PA, the percentage of infested birds was $36.15 \%(n=213)$ and in NY it was $30.61 \%(n=98)$.

There was a statistically significant difference in the number of ticks on each bird based on age ( $\mathrm{p}=0.002, \mathrm{z}=3.084)$ in PA and NY, where the results of the NB regression showed that juveniles (HY) had significantly higher tick loads than adult birds (AHY, SY, ASY) (Table 1-6). There was also a statistically significant association between tick load and family, where Mimids $(\mathrm{p}=0.0219, \mathrm{z}=-2.292$ ) had significantly lower tick loads than the species in other families (Table 1-6). Migratory strategy also showed a statistically significant association with tick load, where short distance migrants $(\mathrm{p}=0.0162, \mathrm{z}=2.405)$ had the largest number of ticks and long distance migrants $(\mathrm{p}=0.0084, \mathrm{z}=2.637$ ) had more ticks than residents (Table 1-6). There were no statistically significant associations between tick load and sex $(\mathrm{p}=0.3264)$, wing length $(p=0.4427)$, season $(p=0.2139)$, or state of capture $(p=0.6205)$. 


\begin{tabular}{ccccc}
\hline & Estimate & SE & Z & pValue \\
\hline (Intercept) & -1.24 & 0.40 & -3.09 & 0.0020 \\
Short & 0.91 & 0.54 & 1.68 & 0.093 \\
Long & 0.80 & 0.41 & 1.95 & 0.051 \\
Age & 0.72 & 0.22 & 3.24 & 0.0012 \\
Mim & -0.68 & 0.42 & -1.60 & 0.11 \\
\hline
\end{tabular}

Table 1-6. Negative Binomial regression results for tick load. Significant negative binomial statistics for association between tick load and the bird characteristics age, fat score, phylogenetic family, and migratory strategy. 


\section{Discussion}

Compared to the average infestation percentages found in the literature $(<6.0 \%)$, an infestation percentage of $36.0 \%$ was found in the 371 individuals of 14 species that were examined. The 14 species that were examined are ground-foraging species, which are more likely to come into contact with ticks than other birds that forage in the canopy of the trees (Rand et al., 1998; Giardina et al., 2000; Comstedt et al., 2006; Loss et al., 2016). Some species, including thrushes, sparrows, and many warblers, are "super-carriers," which are birds that are considered especially likely to carry ticks (Loss et al., 2016). These ground-foraging birds were chosen because including birds that are less likely to encounter ticks (based on foraging habits and behavior) can decrease the magnitude of effect seen with the more likely hosts.

Of all the birds that were examined, the common yellowthroat was the most commonly infested species, which agrees with findings in other studies (Smith et al., 1996; Elias et al., 2010). All 14 of the species that we included in our sample showed higher infestation percentages compared to other birds in various studies, which is one of the reasons they were chosen as focal species (Stafford et al., 1995; Giardina et al., 2000; Richter et al., 2000; Ginsberg et al., 2005; Levi et al., 2016). The high infestation probabilities reported amongst the migrants in this study can be attributed to seasonal migration times in the spring and fall aligning with high nymphal questing activity in the Northeastern United States (CDC, 2016). We hypothesized that the number of nymphs infesting birds would be higher in the spring than the fall based on the life cycle of the ticks, but there was no statistically significant difference in infestation probabilities between the two seasons (Elias et al., 2010). This could be the result of increasing seasonal temperatures, which affects vector survival and reproductive rates, distribution, and feeding activity (Kovats et al., 2001; Gray, 2002; Ogden et al., 2005; Loss et al., 2016). Interstadial development rates of Ixodes scapularis are strongly influenced by ambient temperature, meaning as temperature increases, the rate at which ticks develop into the next life stage increases as well (Ogden et al., 2004). This could alter the seasonal changes in life stage that are expected to occur in the fall, resulting in a greater infestation probability than anticipated based on previous years with more normal temperatures (Kovats et al., 2001; Gray, 2002; Ogden et al., 2005; Loss et al., 2016).

Adult birds were less likely to be infested by ticks than juveniles, and adults also had fewer ticks on them than young birds. Both of these results could be a product of bird development, foraging behavior, and preening strategies which improve as a bird matures (Anders et al., 1998; Bush and Clayton, 2018). Post-fledgling dispersal research indicates that juvenile birds (HY) tend to move away from the feeding areas of adult birds and instead use early and mid-successional forest habitat to forage for food (Anders et al., 1998). Movement to these dense, early successional areas would greatly increase these birds' risk of exposure to ticks, because these habitats are where Ixodes species are most commonly found (Brinkerhoff et al., 2009). Though I did not directly assess behavioral or habitat use differences between adult and juvenile birds, there is sufficient evidence to warrant further investigation.

Birds with less fat, which are considered to be in poorer body condition, were also more likely to be infested than birds with more fat. This is supported by research on the negative effects of parasitism in birds, which includes decreased available energy due to excessive preening and decreased fat for energy storage (Brown et al., 1995). Decreased fats scores in these birds also increases the likelihood of parasitism in birds due to the behavioral changes that occur as a result of poor body condition and decreased energy stores (Bush and Clayton, 2018). Some 
of the anti-parasite behaviors identified in birds include body maintenance, nest maintenance, avoidance of parasitized prey, migration, and tolerance, all of which can be altered once a bird shows a decline in energy or becomes parasitized (Bush and Clayton, 2018).

Mimids had significantly fewer ticks on them than species of other families, which is most likely a result of their large size. These results contradict the pattern of parasitism seen with other ectoparasites, where larger bodied birds typically have larger parasite loads (O'Connor et al., 2010). This could be the result of the Mimids having longer beaks to preen more efficiently than the other species included in the study (Clayton et al., 2005).

There was also a relationship between migratory strategy and tick load. Short-distance migrants had the greatest number of ticks on them, but long distance migrants also had significantly more ticks on them than resident species. Between the two types of migratory birds (short and long distance), long distance migrants could have fewer ticks on them at the time of capture because they were travelling in the air longer than the short distance migrants, which would allow time for the ticks to fall off. This also supports the idea that these birds might be transporting ticks to and from new areas as they migrate. Residents may have the lowest tick loads because the migratory birds could be picking up the ticks elsewhere and introducing them to these locations. By the time they arrive at the banding stations, the ticks could be fully fed and falling off to molt, which would decrease the number of ticks available to infest the resident species. Alternatively, the increased tick loads in migratory birds could also be the result of the demands of migration and the negative effects that it has on the body condition of the birds upon arrival at their stopover site (Brown et al., 1995; Bush and Clayton, 2018). Migration requires birds to use most of their available energy, therefore, migrating birds have less energy to use for preening and maintaining their overall health (Brown et al., 1995). This could explain why residents, who can conserve energy for preening parasites, are infested by less ticks than migratory birds.

Resident and migratory songbird species were included because they both play a role in the movement and establishment of tick populations. Migrants are required for the introduction of vectors to new areas through migration, which includes movement between states, countries, and even continents. Migrating songbirds can travel anywhere from a few hundred to several thousand kilometers over the period of a few weeks (DeLuca, 2015). During this mass migration, ticks can attach to, feed on, and fall off of the birds at various stopover sites along their migratory route (Ogden et al., 2008; Gatewood et al., 2009). Many of these migratory birds pass through the northeastern range of the causative agent of Lyme disease (Borrelia burgdorferi) in the spring and fall, which corresponds with high nymphal Ixodes scapularis questing activity (Brinkerhoff et al., 2009; Scott et al., 2001). This gives these birds the potential to spread the disease over a large distance in a relatively short period of time by transporting infected vectors. The role that resident species play in maintaining tick populations is also important to understand once ticks have been established in an area. Residents could contribute to small scale expansion of tick populations. These birds enhance host diversity by acting as hosts for the ticks to feed on to continue the transmission cycle for many of the diseases that they carry.

To my knowledge, this is the first research examining factors affecting probability of tick infestation and tick loads on birds. Understanding these factors can lead to developments in the prevention and mitigation of the spread of Lyme disease through avian hosts. The knowledge that juvenile (hatch year) birds and birds with lower fat scores are more likely to be infested by ticks provides insight into what makes a bird more likely to be infested by parasites and therefore potentially carry a disease. Similarly, knowing that juveniles and migrants have higher tick loads 
than adults and residents can help people understand their risk of exposure based on the habitat, seasonal behaviors, and types of birds present in their area. Current research on birds as carriers of vectors and disease should focus on studying these and other factors that could lead to predictions about infestation probability. The first step in managing the spread of a disease is understanding the complete cycle of the disease, including all of the vectors, carriers, and hosts involved in its transmission. Therefore, the fields of public health, veterinary medicine, and ecology must all work together to improve the techniques that are currently used for managing the spread of vector-borne disease. 


\section{References}

Anders AD, Faaborg J, and Thompson FR. Postfledgling dispersal, habitat use, and home-range size of juvenile wood thrushes. The Auk. 1998; 115(2):349-358.

Bates D, Machler M, Bolker BM, and Walker SC. Fitting linear mixed-effects models using lme4. Journal of Statistical Software. 2015; 67(1):1-48.

Battaly GR, Fish D, and Dowler RC. The seasonal occurrence of Ixodes dammini and Ixodes dentatus (Acari: Ixodidae) on birds in a Lyme disease endemic area of southeastern New York State. J New York Entomol Soc. 1987; 461-468.

Bradley CA and Altizer S. Urbanization and the ecology of wild- life diseases. Trends Ecol Evol. 2007; 22:95-102.

Brinkerhoff RJ, Folsom-O'Keefe CM, Bent SJ, Tsao K, et al. Genotypic diversity of Borrelia burgdorferi strains detected in Ixodes scapularis larvae collected from North American songbirds. Appl Environ Microbiol. 2010; 76:8265-8268.

Brinkerhoff RJ, Folsom-O'Keefe CM, Streby HM, Bent SJ, et al. Regional variation in immature Ixodes scapularis parasitism on North American songbirds: Implications for transmission of the Lyme pathogen, Borrelia burgdorferi. J Med Entomol. 2011; 48(2):422-428.

Brinkerhoff RJ, Folsom-O'Keefe CM, Tsao K, and Diuk-Wasser MA. Do birds affect Lyme disease risk? Range expansion of the vector-borne pathogen Borrelia burgdorferi. Front Ecol Environ. 2009.

Brown, CR, Brown MB, and Rannala B. Ectoparasites reduce the long-term survival of their avian host. Proc R Soc Lond B. 1995; 262:313-319.

Burgdorfer W, Hayes SF, and Corwin D. Pathophysiology of the Lyme disease spirochete, Borrelia burgdorferi, in Ixodid ticks. RevInfect Dis. 1989; 11(6):S1442-1450.

Burnham KP and Anderson DR. 2002. Model selection and multimodel inference: a practical information-theoretic approach. Springer, New York, New York, USA.

Bush SE, Clayton DH. Anti-parasite behaviour of birds. Phil Trans R Soc B. 2018; 373:20170196.

Centers for Disease Control and Prevention (CDC). Tickborne Diseases of the United States. Retrieved from http://www.cdc.gov/ticks/diseases/index.html. 2016.

Clayton DH, Moyer BR, Bush SE, et al. Adaptive significance of avian beak morphology for ectoparasite control. Proc R Soc Lond B. B: Biological Sciences. 2005; 272(1565):811-817. 
Cohen EB, Auckland LD, Marra PP, and Hamer SA. Avian migrants facilitate invasion of neotropical ticks and tick-bonre pathogens into the United States. Appl and Environ Microbiol. 2015; 81(24):8366-8378.

Comstedt P, Bergstrom S, Olsen B, Garpmo U, et al. Migratory Passerine Birds as Reservoirs of Lyme Borreliosis in Europe. Emerg Infect Dis. 2006; 12(7):1087-1095.

Cornell Lab of Ornithology. 2014. All About Birds. All About Bird Biology <birdbiology.org>. Cornell Lab of Ornithology, Ithaca, New York.

De Oliveira SV, Dos Santos J, Gustavo Aver, Correa LC, et al. Serological evidence of Lyme disease and possibleintroduction of Borrelia along migratory bird routes in Brazil. Vector Biol J. 2018; $3: 1-4$.

DeLuca WV, Woodworth BK, Rimmer CC, Marra PP, et al. Transoceanic migration by a 12g songbird. Biol Lett. 2015; 11:20141045.

Dubska L, Literak I, Kocianova E, Taragelova V, et al. Differential role of passerine birds in distribution of Borrelia spirochetes, based on data from ticks collected from birds during the postbreeding migration period in central Europe. Appl. Environ. Microbiol. 2009; 75:596-602.

Elias SP, Smith RP, Morris SR, Rans PW, et al. Density of Ixodes scapularis ticks on Monhegan Island after complete deer removal: A question of avian importation. J Vect Ecol. 2010; 36(1):11-23.

Gatewood AG, Liebman KA, Vourc'h G, Bunikis J, et al. Climate and tick seasonality predict Borreila burgdorferi genotype distribution. Appl Environ Microbiol. 2009; 75:2476-2483.

Giardina AR, Schmidt KA, Schauber EM, and Ostfeld RS. Modeling the role of songbirds and rodents in the ecology of Lyme disease. Canadian J of Zoology. 2000; 78:2184-97.

Ginsberg HS, Buckley PA, Balmforth MG, Zhioua E, et al. Reservoir competence of native North American birds for the Lyme disease spirochete, Borrelia burgdorferi. J Med Entomol. 2005; 42: 445-449.

Gray JS. Biology of Ixodes species ticks in relation to tick-borne zoonoses. Wien Klin Wochenschr. 2002; 114:473-478.

Hamer SA, Goldberg TL, Kitron UD, Brawn JD, et al. Wild birds and urban ecology of ticks and tickborne pathogens, Chicago, Illinois, 2005-2010. Emerg Inf Dis. 2012; 18(10): 1589-95.

Hubálek Z. An annotated checklist of pathogenic microorganisms associated with migratory birds. J Wildl Dis. 2004; 40:639-659.

Kovats RS, Campbell-Lendrum DH, McMichael AJ, Woodward A, et al. The effects of climate change: do they include changes in vector-borne disease? Phil Trans R Soc Lond B. 2001; 356:10571068 . 
Levi T, Keesing F, Holt RD, Barfield M, et al. Quantifying dilution and amplification in a community of hosts for tick-borne pathogens. Ecol Appl. 2016; 26(2):484-498.

LoGuidice K, Ostfeld RS, Schmidt KA, and Keesing F. The ecology of infectious disease: effects of host diversity and community composition on Lyme disease risk. P Natl Acad Sci USA. 2003; 100:567-571.

Loss SR, Noden BH, Hamer GL, and Hamer SA. A quantitative synthesis of the role of birds in carrying ticks and tick-borne pathogens in North America. Oecologia. 2016; 182:947-959.

Mazerolle MJ. AICcmodavg: Model selection and multimodel inference based on (Q)AIC(c). R package version 20-4. 2016.

O’Connor J, Sulloway F, Robertson J, and Kleindorfer S. Philornis downsi parasitism is the primary cause of nestling mortality in the critically endangered Darwin's medium tree finch (Camarhynchus pauper). Biodivers Conserv. 2009; 19:853-866.

Ogden NH, Bigras-Poulin M, O'Callaghan CJ, et al. A dynamic population model to investigate effects of climate on geographic range and seasonality of tick Ixodes scapularis. Int J Parasitol. 2005; 35:375-389.

Ogden NH, Lindsay LR, Beauchamp G, Charron D, et al. Investigation of the relationships between temperature and development rates of the tick Ixodes scapularis (Acari: Ixodidae) in the laboratory and field. J Med Entomol. 2004; 41: 622-633.

Ogden NH, Lindsay LR, Hanincova K, Barker IK, et al. Role of migratory birds in introduction and range expansion of Ixodes scapularis ticks and of Borrelia burgdorferi and Anaplasma phagocytophilum in Canada. Appl Environ Microbiol. 2008; 74:1780-1790.

Ogden NH, Maarouf A, Barker IK, Bigras-Poulin M, et al. Projections for range expansion of the Lyme disease vector Ixodes scapularis, in response to climate change. Int J Parasitol. 2006; 36:63-70.

Pyle, P. 1997. Identification guide to North American birds. Slate Creek Press, Bolinas, CA.

R: A language and environment for statistical computing. $\mathrm{R}$ foundation for statistical computing, Vienna, Austria. R Core Team. 2014.

Rand PW, Lacombe EH, Smith RP Jr, and Ficker J. Particiation of birds (Aves) in the emergence of Lyme disease in southern Maine. J Med Entomol. 1998; 35:270-276.

Rappole JH and Hubálek Z. Migratory birds and West Nile virus. J Appl Microbiol. 2003; 94:47S-58S.

Richter D, Spielman A, Komar N, and Matuschka FR. Competence of American robins as reservoir hosts for Lyme disease spirochetes. Emerg Inf Dis. 2000; 6:133-138.

Schneider AC, Parker CM, Miller JR, Fredericks LP, et al. Assessint the contribution of songbirds to the movement of ticks and Borrelia burgdorferi in the Midwestern United States during fall migration. EcoHealth. 2015; 12:164-173. 
Scott JD, Fernando K, Banerjee SN, Durden La, et al. Birds disperse ixodid (Acari: Ixodidae) and Borrelia burgdorferi-infected ticks in Canada. J Med Entomol. 2001; 38:493-500.

Smith RP Jr., Rand PW, Lacombe EH, Morris SR, et al. Role of bird migration in the long-distance dispersal of Ixodes dammini, the vector of Lyme disease. J Infect Dis. 1996; 174:221-224.

Smith SB, Miller AC, Merchant CR, and Sankoh AF. Local site variation in stopover physiology of migrating songbirds near the south shore of Lake Ontario is linked to fruit availability and quality. Conserv Phys. 2015; 3(1): cov036.

Stafford KC, Bladen VC, and Magnarelli LA. Ticks (Acari: Ixodidae) infesting wild birds (Aves) and white-footed mice in Lyme, CT. J Med Entomol. 1995; 32(4):453-466.

Stickel LF. Home range and travels. Amer Soc Mamm. 1968; 2:373-411.

Stokes ME, Davis CS, and Koch GG. 2012. Categorical Data Analysis using SAS, Third Edition. Cary, NC: SAS Institute Inc.

Sutherst RW. Global change and human vulnerability to vector-borne diseases. Clin Microbiol Rev. 2004; 17(1):136-173.

Telford SR, Mather TN, Moore SI, Wilson ML, et al. Incompetence of deer as reservoirs of the Lyme disease spirochete. Am J Trop Med Hyg. 1988; 39:105-109.

Venables WN and Ripley BD. 2002. Modern Applied Statistics with S. Fourth Edition. Springer, New York. ISBN 0-387-95457-0.

Widmann RH. 2016. Forests of New York, 2015. Resource Update FS-96. Newtown Square, PA: U.S. Department of Agriculture, Forest Service, Northern Research Station. 4 p.

Young, AH, Knapp KR, Inamdar A, Rossow WB, et al. "The International Satellite Cloud Climatology Project, H-Series Climate Data Record Product," Earth System Science Data, in preparation. 2017.

Zeileis A, Kleiber C, and Jackman S. Regression models for count data in R. Journal of Statistical Software. 2008; 27(8).

Zolnierowicz KM, Ondrova-Nyklowa M, and Tobolka M. Sex differences in preening behavior in the White Stork (Ciconia ciconia). Pol J Ecol. 2016; 64:406-410. 


\section{CHAPTER 2: GROUND-DWELLING SONGBIRDS AS RESERVOIRS AND CARRIERS OF LYME DISEASE}

\section{Introduction}

Lyme disease accounts for more than $90 \%$ of all vector-borne disease in the United States with 20,000 human cases reported annually (Hamer et al., 2010; CDC, 2016). Lyme disease is caused by the bacterium Borrelia burgdorferi, which is a complement-resistant spirochete capable of varying its gene expression to adapt to a variety of host environments (Burgdorfer et al., 1982; Tilly et al., 2008; CDC, 2016). The specific strain that causes infection in the United States is Borrelia burgdorferi sensu stricto, and its geographic range continues to expand, though the mechanisms and causes for this expansion remain unknown (Bacon et al., 2008). In the northeastern United States, Ixodes scapularis, commonly referred to as the black-legged tick, is the most common vector of Borrelia burgdorferi (Bacon et al., 2008; CDC, 2016). The epizootic spread of Borrelia burgdorferi in the northeast is directly linked to a regional increase in the population density of Ixodes scapularis ticks and an expansion in their range, therefore, understanding dispersal mechanisms of these ticks is crucial to understanding the spread of Lyme disease (Kurtenbach et al., 2006; Hamer et al., 2011; CDC, 2016).

The primary vector of Lyme disease (Ixodes scapularis) has a two-year life cycle. Ticks hatch from their eggs in the spring and emerge as six-legged larvae, which feed on small mammals and sometimes birds before dropping off and going dormant for almost an entire year. This initial feeding is the tick's first opportunity to acquire the Borrelia burgdorferi bacterium, which it maintains through successive molts. These larvae then molt into eight-legged nymphs, re-emerging the following spring to feed on and potentially pass the pathogen onto small mammals, birds, and often humans. These nymphs undergo a final molt into an eight-legged adult stage that feeds on larger mammals and humans before falling off, mating, and laying eggs for the next generation to begin its life cycle. Each feeding is an opportunity for the ticks to acquire the Borrelia burgdorferi from its host or transmit the pathogen to a novel host (Burgdorfer and Gage, 1986; Tilly et al., 2008). Most contemporary research on tick-host-disease interaction in the northeast focuses on the role that mammals play in the spread of Lyme disease (LoGuidice et al., 2003; Ginsberg et al., 2005; Levi et al., 2016). However, determining the roles that alternative hosts play in tick-borne disease transmission and range expansion is crucial to understanding the complete enzootic cycle of the disease (Ogden et al., 2006; Bradley and Altizer, 2007; Levi et al., 2016).

Migratory songbirds are associated with long-distance dispersal of zoonotic diseases because they travel anywhere from a few hundred to several thousand kilometers during migration (Hubálek et al., 2004; Ogden et al., 2008; DeLuca et al., 2015). In North America, >70 species of songbird (Passeriformes) have been documented as hosts for Ixodes scapularis ticks, and $56 \%$ of these species are potentially competent reservoirs for the Borrelia burgdorferi bacterium (Brinkerhoff et al., 2009). Research on the role that birds play in the transmission of Lyme disease throughout the United States has increased. Specifically, rates of bird infestation by ticks and tick infection prevalence provide insight into frequency of the pathogen, however, there has been little emphasis placed on testing bird blood despite their documented competence as reservoirs for the bacterium (Stafford et al., 1995; Rand et al., 1998; Brinkerhoff et al., 2010, 2011; Elias et al., 2010; Hamer et al., 2012; Cohen et al., 2015; Schneider et al., 2015). Research 
reporting low infestation rates $(<6.0 \%)$ also found low prevalence of Borrelia burgdorferi infection $(<13.0 \%)$ in the ticks removed from the birds, even in regions where there is an infection prevalence of $25.0-35.0 \%$ in questing nymphs (Kurtenbach et al., 2006; Elias et al., 2010; Loss et al., 2016).

I explored the potential role of 14 species of ground-dwelling songbirds as carriers of Borrelia burgdorferi (Table 1-1). My objectives were to (1) determine the prevalence of Borrelia burgdorferi in bird blood and Ixodes scapularis ticks removed from songbirds, (2) compare the infection prevalence between birds that were infested with ticks at the time of capture and those that were not infested, and (3) determine what bird characteristics (sex, age, mass, wing length, fat score, season, location, phylogenetic family, migratory strategy; Table 1-2) are associated with finding Borrelia burgdorferi positive blood or ticks on birds. I hypothesize that greater infestation by Ixodes scapularis ticks in birds will correlate with greater prevalence of Borrelia burgdorferi in the ticks removed from the birds than previously reported in this region. Also, I hypothesize that the infection prevalence of Borrelia burgdorferi in songbirds will be the same in infested birds compared to those that were not carrying ticks at the time of capture. I believe that females, young birds (hatch year), birds with lower fat scores, birds with smaller masses, and members of the Parulid family will be more likely to be infested by Borrelia burgdorferi positive ticks and have Borrelia burgdorferi positive blood based on their preening ability and overall health (Brown et al., 1995; Anders et al., 1998; Clayton et al., 2005; Zolnierowicz et al., 2016; Bush and Clayton, 2018). I hypothesize that the birds in NY will be infested by the most Borrelia burgdorferi positive ticks based on the documented prevalence of Borrelia burgdorferi within each state (CDC, 2016). Lastly, I expect birds examined in the fall to have more Borrelia burgdorferi positive ticks and blood than those in the spring based on the temporal component of the life cycle of the ticks that are parasitizing them (CDC, 2016; Gatewood et al., 2009).

\section{Methods}

\section{Study Area}

This study focused in the Northeastern United States, where Lyme disease is highly endemic. Samples were collected from sites in Pennsylvania, New York, and West Virginia. Both PA and NY were chosen because they are in the top 5 for Lyme disease prevalence in the country, Ixodes scapularis is prevalent there, and they are high incidence states for Lyme disease (CDC, 2016). WV was chosen due to its proximity to these other high incidence states and its recent transition to endemic strategy for Lyme disease (CDC, 2016). The average incidence rate of confirmed cases of Lyme disease per 100,000 people in PA, NY, and WV from 2014-2016 was 59.4, 14.7, and 11.8, respectively.

Partnerships were established with banding stations in each of the 3 states to maximize the number of birds captured. Powdermill Avian Research Center (PARC) is located on a 10 hectare plot of fields, hedgerows, and marshy ponds with alder (Alnus glutinosa) and willow (Salix bebbiana)-lined streams in Stahlstown, PA. It is located at an elevation of 411.5 kilometers (1,350 feet) above sea level and is bordered by deciduous forest and low-intensity agricultural fields of corn (Zea mays) in the Ligonier Valley to the west. Forests are primarily comprised of maple (Acer saccharum), oak (Quercus robur), and hickory (Carya ovata) trees. Average temperature during spring migration (mid-April to June) ranges from a high of $16.67^{\circ}-26.67^{\circ} \mathrm{C}$ to a low of $1.67^{\circ}-11.11^{\circ} \mathrm{C}$ with an average rainfall of $10.41-11.18 \mathrm{~cm}$ (Young et al., 2017). During 
fall migration (mid-August to October), average temperatures range from a high of $16.67^{\circ}$ $28.89^{\circ} \mathrm{C}$ and a low of $2.22^{\circ}-13.33^{\circ} \mathrm{C}$ with an average rainfall of $8.13-10.67 \mathrm{~cm}$ (Young et al., 2017).

The Braddock Bay Bird Observatory (BBBO) in Rochester, NY is located along the south shore of Lake Ontario at an elevation of around 91.4 kilometer (300 feet) above sea level. It is bordered by the lake, agricultural fields, and suburban land, and the habitat is primarily early successional deciduous forest consisting mainly of sugar and red maple (Acer rubrum), red oak (Quercus rubra), hemlock (Tsuga maculatum), and American beech (Fagus grandifolia) trees with patchy shrubs (Smith et al., 2015; Widman, 2016). Average temperatures during spring migration range from a high of $13.33^{\circ}-25.00^{\circ} \mathrm{C}$ to a low of $2.22^{\circ}-13.33^{\circ} \mathrm{C}$ with an average rainfall of 7.11-8.64 cm (Young et al., 2017).

The AFMO in Dolly Sods, WV is located on the high ridge of Allegheny Front Mountain in the Monongahela National Forest at an elevation of (4,000 feet) above sea level. The rocky plateau is covered by red spruce trees and second-growth forest, including aspen, mountain ash, huckleberry, and blueberry bushes. The average temperature during fall migration ranges from a high of $15.00^{\circ}-23.89^{\circ} \mathrm{C}$ to a low of $1.11^{\circ}-10.00^{\circ} \mathrm{C}$ with an average rainfall of $8.89-11.94 \mathrm{~cm}$ (Young et al., 2017).

\section{Bird Capture and Focal Species Sampling}

A random sample of mist-netted birds were examined at each station during the spring and fall migrations of 2017. In the spring of 2017, birds at the PARC were examined for 3 days at the beginning (4/26-4/28) and 3 days at the end of spring (5/16-5/18). Birds from BBBO were examined for 3 days in early May (5/11-5/13) and 3 days in late May (5/22-5/24). Birds were examined during the fall migration of 2017 at PARC for 3 days in mid- September (9/14-9/16) and during 2 separate 2-day sampling periods in early (9/3-9/4) and late (9/23-9/24) September at the AFMO. Opportunistic searching was also conducted by lead banders at the banding stations in PA in the spring $(5 / 3,5 / 21,5 / 23,5 / 27,5 / 28,5 / 31), N Y$ in the spring $(5 / 16,5 / 18,5 / 19,5 / 20$, $5 / 21)$, and in WV in the fall $(9 / 8,9 / 9,9 / 16,9 / 17)$.

Birds were mist-netted using $30 \mathrm{~mm}$ mesh mist nets that were opened at sunrise and closed 6 hours later. There were 70 nets open at the PARC, 32 at BBBO, and 45 at AFMO. The nets were checked for birds every 30 minutes, and all birds found were transported back to the banding station in cloth or paper extraction bags. Each bird was banded, identified to species, and sexed, and 2 of the stations (PARC and BBBO) also reported a fat score, wing length, and mass for each bird (Pyle, 1997). Then, the 14 focal species were searched for ticks and blood samples were collected from a random sample of these birds. All bird handling, tick collection, and blood collection was done under West Virginia University IACUC \#1704005815 and USFWS Federal Permit \#08231.

Tick searches were performed on 13 of the species during spring sampling and an additional species was included for the fall sampling (Swainson's thrush) because it is a common ground-dwelling fall migrant captured at each banding station. Each bird was inspected for approximately 30 seconds, and birds were searched around the head, neck, ears, eyes, and beak for ticks (Hamer et al., 2012). All ticks were removed using forceps and stored in cryogenic vials of ethanol for 2-6 months before processing (Hamer et al., 2011). After the tick search, all infested birds and a random sample of non-infested birds were held to have their blood drawn before release. All other birds were released after completion of the tick search. 
Blood was collected from all tick-infested birds and a random sample of infested and non-infested birds to test the species' reservoir competency for Borrelia burgdorferi. Blood was collected under IACUC protocol \#1704005815 from West Virginia University. Brachial venipuncture was performed using a 28-gauge needle to puncture the vein, and heparinized capillary tubes were used to collect the blood. The volume of blood collected from each bird was no greater than $1 \%$ of its body weight, or $10 \%$ of its total blood volume (50 $\mu \mathrm{L}$ of blood drawn from birds that weigh between 12 and $19.9 \mathrm{~g}$ and $100 \mu \mathrm{L}$ of blood drawn from birds that weigh greater than $20 \mathrm{~g}$; Cohen et al., 2015). After the blood was collected, it was transferred from the capillary tubes to a purple top EDTA (anticoagulant) tube and stored at $-20^{\circ} \mathrm{C}$ until processing. Each bird was held for observation for no fewer than 2 minutes and released once it was determined that the flow of blood had stopped. No birds ever showed signs of stress as a result of blood draws, nor were any unable to fly.

\section{Pathogen Screening and Tick Speciation}

Infestation rates for nymph and larval ticks removed from song birds were calculated after identifying ticks to genus Ixodes utilizing the identification key "The genus Ixodes in North America" (Cooley and Kohls, 1945). Infestation rates were limited to genus level as identifying field collected nymph and larval Ixodes to species is often difficult, and can result in misclassification. Instead, speciation of Ixodes ticks was limited to Ixodes species ticks which tested positive in our two stage confirmatory PCR test. Ticks and blood samples collected from birds were screened for Borrelia burgdorferi using conventional PCR methodologies. DNA was extracted using the Fermentas GeneJET Genomic DNA Purification kit. Ticks were bisected using a sterile scalpel blade to increase the DNA yield extracted from each tick. Quantitative real-time PCR (qPCR) was used to amplify the 16s rRNA gene of Borrelia burgdorferi using primers and a pathogen-specific Taqman probe, based on methods modified from Courtney et al. (2004). Nested PCR and gel electrophoresis were utilized as a confirmatory test to identify the Borrelia burgdorferi Lyme group in the Ixodes species ticks that tested positive with the qPCR based on methods modified from Norris et al. (1996). The gel used was $1.5 \%$ agarose gel stained with ethidium bromide. The DNA was extracted from the gel utilizing the Thermo scientific GeneJET DNA Purification kit and sequenced to confirm Borrelia burgdorferi positivity.

\section{Data Analysis}

Birds were not separated into individual species for analysis due to the variation in numbers of each species caught across both seasons, so species were instead grouped by family (Thrushes, Mimids, Parulids, and others) for analysis. Also, data from WV was excluded from the logistic regression and Negative Binomial regression due to the lack of information recorded and the insufficient sample size collected from this state. The tick infestation percentage was calculated by dividing the number of birds that were infested by at least one tick by the total number of birds captured and searched for ticks.

A logistic regression $(n=311)$ was run using package lme 4 in program $\mathrm{R}$ to model the association between the independent variables (sex, age, mass, wing length, fat score, season, location, phylogenetic family, migratory strategy) and the binary outcomes (Borrelia burgdorferi positive vs. negative ticks and Borrelia burgdorferi positive vs. negative blood) (Stokes et al., 2012; Bates et al., 2015). For individuals with data missing for a single independent variable, the 
missing value was replaced with the mean value, which was calculated using the values from other individuals of the same species. Some birds were completely omitted due to missing data for multiple independent variables. A global model including all of the independent variables was run first to determine the parameter significance. Then, any parameter with a Wald's test absolute value $\mathrm{z}>1.64$ was considered significant, which equates to a significant $\alpha<0.1$. Using the Wald's test statistic, the models were re-run and the parameters were evaluated, only considering parameters to be significant if the confidence interval did not overlap zero. Finally, package AICcmodavg in program $\mathrm{R}$ was used for model comparison with Aikaike's information criterion adjusted for small sample sizes (AICc) (Burnham and Anderson, 2002, Mazzerolle, 2016). The reduce model was considered to be the top model if $\triangle \mathrm{AICc}<2.0$.

The count of the number of Borrelia burgdorferi positive ticks on each bird was used to model the effect of the factors being tested. Due to the over dispersion present and the large number of 0 's in the data (0 ticks), 3 separate distributions were used; Poisson using package lme4 in program R (Bates et al., 2015), Negative Binomial (NB; using package MASS in program R (Venables and Ripley, 2002), and Zero-inflated Poisson (ZIP) using package pscl in program R (Zeileis et al., 2008). Regression was used to test the association between the continuous variable number of positive ticks and each of the independent variables (sex, age, mass, wing length, fat score, season, state of capture, phylogenetic family, migratory strategy; Table 1-2) (Zeileis et al., 2008). To determine parameter significance, the same procedure from the logistic regression modeling was used. All predicted probabilities (predicted number of Borrelia burgdorferi positive ticks) across the range for significant independent variables were estimated while holding all other parameters that were significant at the mean value.

\section{Results}

\section{Bird Capture and Focal Species Sampling}

During the spring and fall migrations of 2017, a total of 371 songbirds of 14 different species were examined. In the spring, 190 individuals of 13 different species were examined, and 181 individuals of 12 species were examined in the fall. A total of 222 birds were examined in PA (spring and fall), 109 birds in NY (spring), and 40 birds in WV (fall) (Table 1-2).

A total of 132 birds $(n=371 ; 35.6 \%)$ were infested by 297 nymphs. The average number of ticks per infested bird was $2.25 \pm 0.20$. There were 126 ticks tested in the Spring and 144 ticks tested in the Fall, with 181 collected in PA, 62 in NY, and 27 in WV. The overall infestation in the spring was $31.6 \%(n=190)$ and in the fall it was $39.2 \%(n=181)$. PA had an infestation percentage of $36.9 \%(n=222)$ in the spring and fall, NY had an infestation percentage of $33.0 \%$ in the spring $(n=109)$, and WV had an infestation percentage of $32.5 \%$ in the fall $(n=40)$.

The logistic regression revealed that the probability of finding a Borrelia burgdorferi positive tick on a bird increases to a threshold. Once a bird had approximately six ticks on it, at least one of the ticks tested positive for Borelia burgdorferi (Figure 2-1). Also, there was an association between probability of finding Borrelia burgdorferi positive ticks on a bird and their fat score $(p<0.05, \mathrm{z}=-2.84$; Table $2-1)$. There was no statistically significant association between infestation by a Borrelia burgdorferi positive tick and the other variables (Table 2-2). 


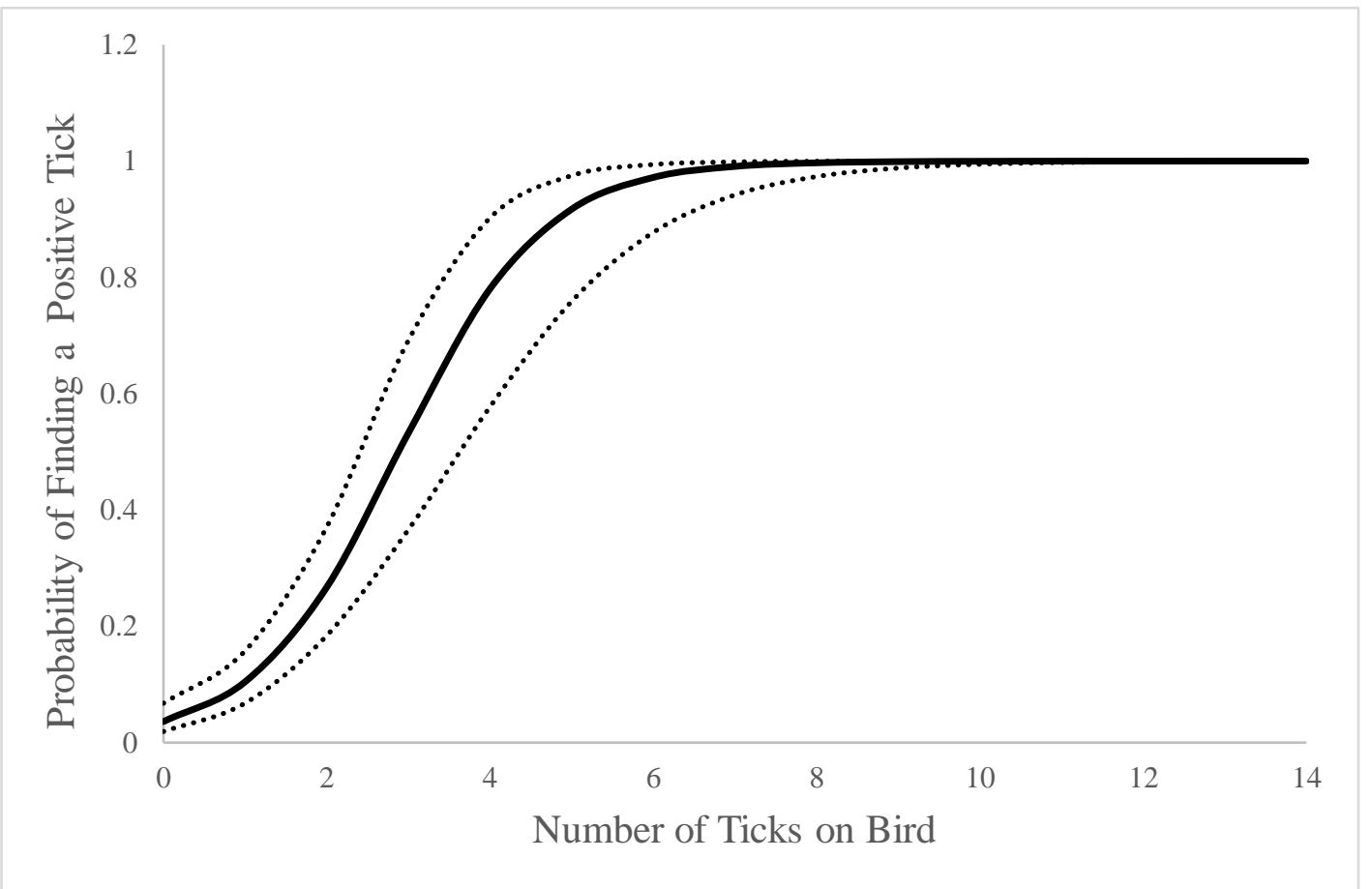

Figure 2-1. Logistic regression results for Borrelia burgdorferi positive tick threshold. Logistic regression of probability of finding a Borrelia burgdorferi positive tick base on the number of ticks present on a bird.

\begin{tabular}{ccccc}
\hline & Estimate & $\mathbf{S E}$ & $\mathbf{Z}$ & $\mathbf{P r}>\mathbf{Z}$ \\
\hline (Intercept) & -2.52 & 0.32 & -7.82 & $5.35 \mathrm{E}-15$ \\
Load & 1.13 & 0.17 & 6.82 & $9.53 \mathrm{E}-12$ \\
Fat & -0.58 & 0.22 & -2.60 & 0.0093 \\
\hline
\end{tabular}

Table 2-1. Logistic regression results for infestation by a Borrelia burgdorferi positive tick. Significant parameter estimates from logistic regression models for associations between the probability of removing a Borrelia burgdorferi positive tick and the significant bird characteristic fat score. 


\begin{tabular}{cccccc}
\hline & AICc & DAICc & AICcWt & Cum.Wt & LL \\
\hline Load+Fat & 169.16 & 0 & 0.52 & 0.52 & -81.54 \\
Load+State+Fat & 169.36 & 0.2 & 0.48 & 1 & -80.61 \\
Global & 186.94 & 17.78 & 0 & 1 & -77.66 \\
Constant & 251.93 & 82.77 & 0 & 1 & -124.96 \\
\hline
\end{tabular}

Table 2-2. Model selection results for infestation by a Borrelia burgdorferi positive tick. AIC Table reporting on competitive models of infestation by Borrelia burgdorferi positive ticks in PA and NY during spring and fall migration. 
All three tests showed agreement in their results, but the results from the Negative Binomial will be reported because they were the best fit for the data (Table 2-1). When data from WV and missing data were excluded from the analysis, there were 213 birds from PA (spring and fall) and 98 birds from NY (spring) included, totaling 311 birds for logistic regression, NB, and ZIP analysis. The overall infestation percentage for the PA and NY birds was $34.41 \%$ $(n=311)$, and they were infested by a total of 243 ticks. Infestation in the spring was $31.58 \%$ $(n=190)$, and in the fall it was $36.36 \%(n=121)$. In PA, the percentage of infested birds was $36.15 \%(n=213)$ and in NY it was $30.61 \%(n=98)$ (Table 1-2). The results of the NB regression showed that individual birds in PA with a fat score of 0 were $92.5 \%$ more likely to be infested with Borrelia burgdorferi positive ticks than those with a fat score of 4 (Figure 2-2; Table 2-3). There was no statistically significant association between number of Borrelia burgdorferi positive ticks and the other independent variables.

\section{Pathogen Screening and Tick Speciation}

Of the 297 ticks removed from birds, 270 were tested. In 270 ticks collected from 50 different birds in PA. NY, and WV, 26.7\% of the ticks tested positive for Borrelia burgdorferi (Figure 2-3). In the spring, 30.7\% (n=127) of the ticks tested were Lyme-positive and $23.1 \%$ $(n=143)$ were positive in the fall. Infection prevalence in ticks in PA, NY, and WV were $27.6 \%$ $(n=184), 30.7 \%(n=62)$, and 4.2\% ( $n=24)$ respectively.

Blood samples were collected from 178 birds, both infested $(n=75)$ and non-infested $(n=103)$. In total, 14 (7.9\%) of the blood samples collected from 9 different species tested positive for Borrelia burgdorferi (Table 2-4). The species with the largest percentage of Borrelia burgdorferi positive blood samples was the Hooded warbler with $21.43 \%(n=14)$ of the blood collected testing positive for Borrelia burgdorferi. None of the independent variables were statistically significant predictors of Borrelia burgdorferi positive blood samples, however, this could be attributed to the small sample size of Borrelia burgdorferi positive blood samples collected. In the Fall, 6 (5.4\%) of the blood samples collected were Borrelia burgdorferi positive compared to $8(12.1 \%)$ of the blood samples collected in the Spring. None of the Borrelia burgdorferi positive blood samples came from birds that were infested with Borrelia burgdorferi positive ticks. There was also a greater proportion of birds with Borrelia burgdorgeri positive ticks and negative blood $(n=22)$ than individuals with negative ticks and Borrelia burgdorferi positive blood $(n=6)$. In total, $8(7.8 \%)$ of the blood samples collected from non-infested birds tested positive for Borrelia burgdorferi and $6(8.0 \%)$ of the blood samples collected from infested birds tested positive Borrelia burgdorferi. 


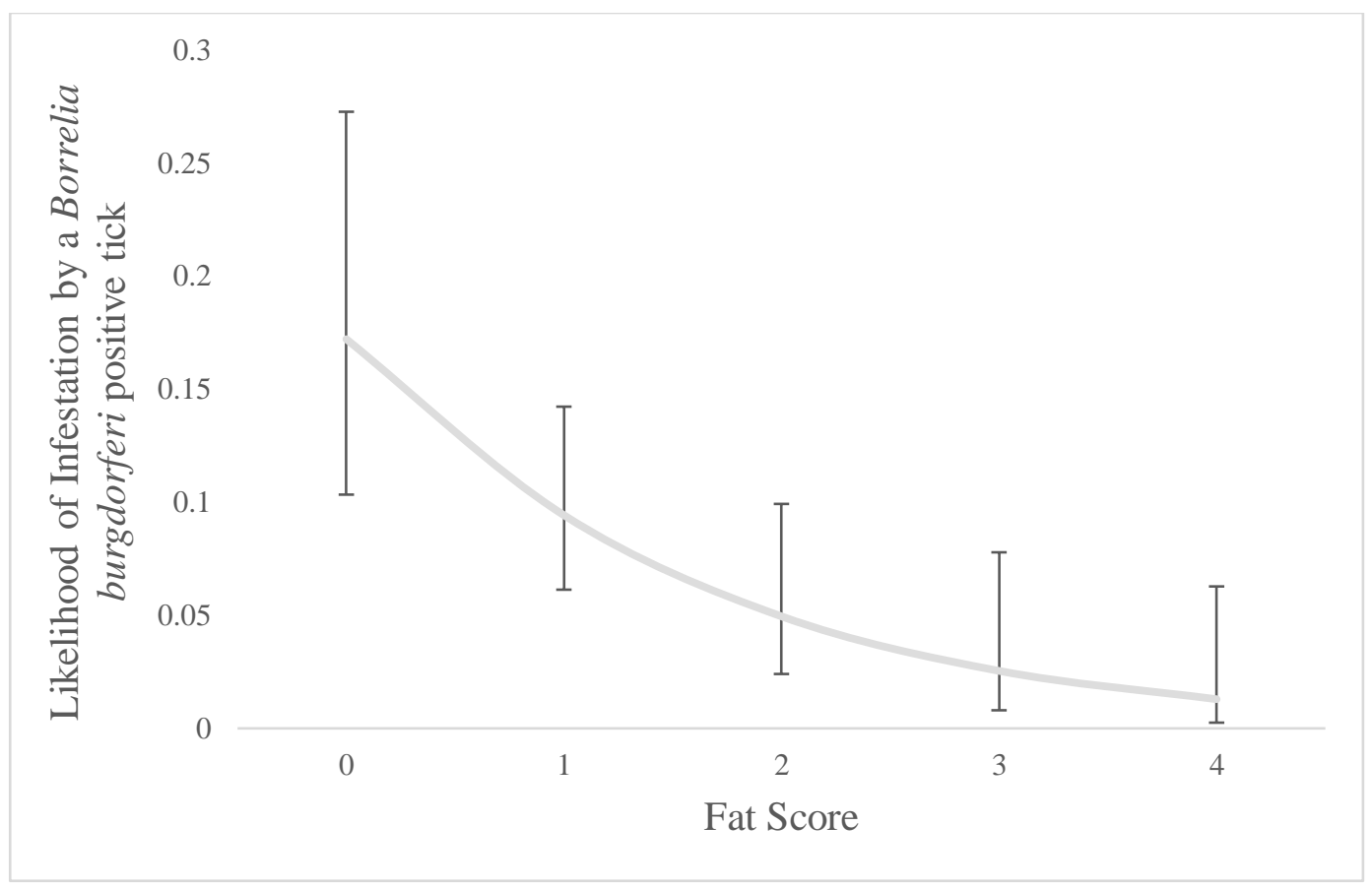

Figure 2-2. Logistic regression results for infestation by a Borrelia burgdorferi positive tick. Logistic regression of association between fat score and probability of removing a Borrelia burgdorferi positive tick form a bird.

\begin{tabular}{ccccc}
\hline & Estimate & SE & $\mathbf{z}$ & pValue \\
\hline (Intercept) & -2.41 & 0.69 & -3.49 & 0.00048 \\
PA & 0.64 & 0.40 & 1.59 & 0.11 \\
Short1 & 0.40 & 0.69 & 0.59 & 0.56 \\
Long1 & 0.72 & 0.63 & 1.15 & 0.25 \\
Fat & -0.24 & 0.17 & -1.38 & 0.17 \\
\hline
\end{tabular}

Table 2-3. Negative Binomial regression results for number of Borrelia burgdorferi positive ticks. Negative binomial statistics for association between number of Borrelia burgdorferi positive ticks removed and the significant bird characteristic fat score. 


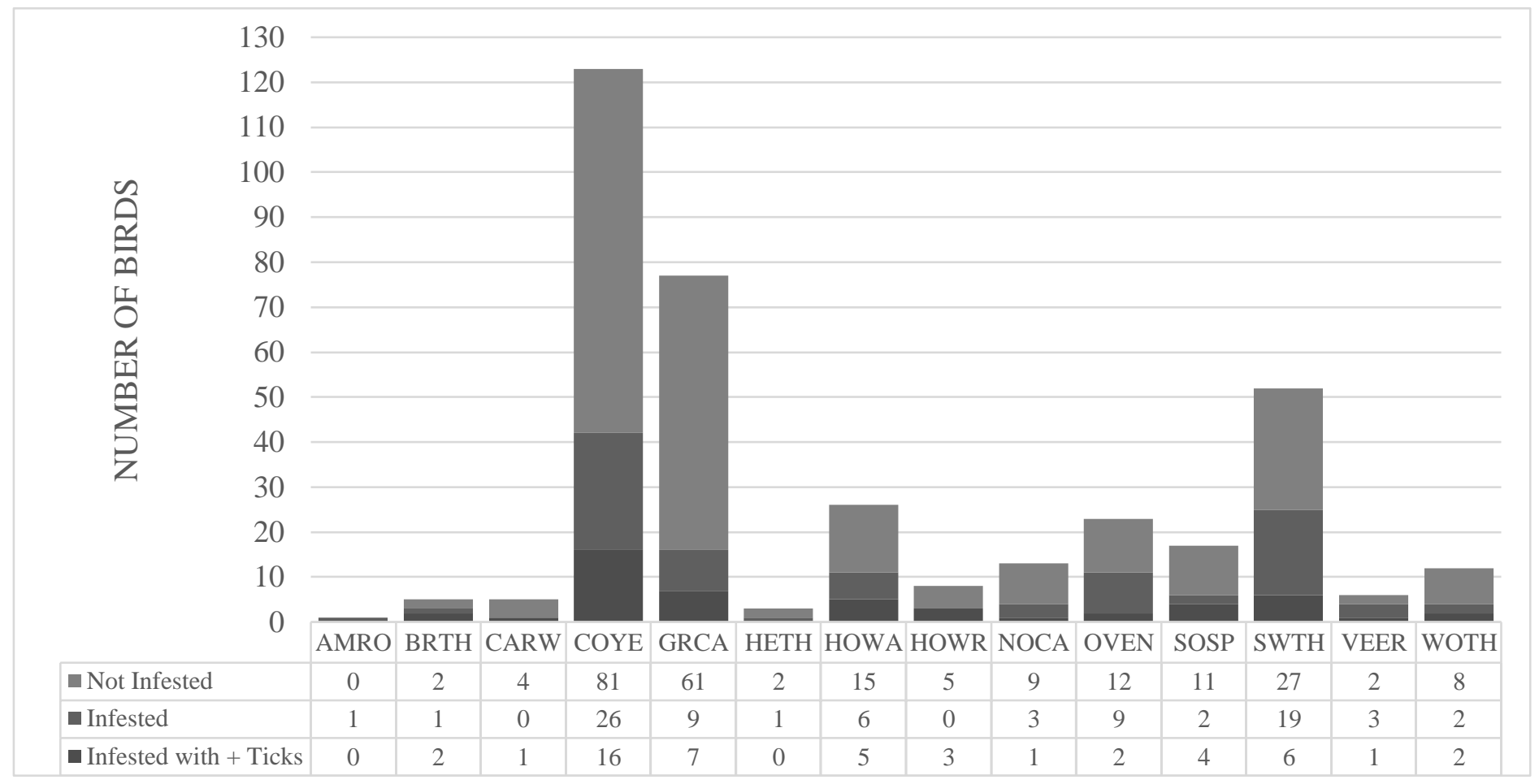

Figure 2-3. Infestation summary by species. Proportion of birds not infested, infested, or infested by Borrelia burgdorferi positive ticks based on species. 


\begin{tabular}{|c|c|c|c|c|c|c|}
\hline Common Name & Examined & Infested & $\begin{array}{c}\text { Ticks } \\
\text { Collected }\end{array}$ & $\begin{array}{c}\text { Positive } \\
\text { Ticks }\end{array}$ & $\begin{array}{c}\text { Blood } \\
\text { Collected }\end{array}$ & $\begin{array}{c}\text { Positive } \\
\text { Blood }\end{array}$ \\
\hline American Robin & 1 & 1 & 6 & 0 & 1 & 0 \\
\hline Brown Thrasher & 5 & 3 & 16 & 3 & 4 & 0 \\
\hline Carolina Wren & 5 & 1 & 7 & 4 & 2 & 1 \\
\hline Common Yellowthroat & 123 & 42 & 77 & 20 & 32 & 2 \\
\hline Gray Catbird & 77 & 16 & 25 & 9 & 38 & 3 \\
\hline Hermit Thrush & 3 & 1 & 1 & 0 & 2 & 1 \\
\hline Hooded Warbler & 26 & 11 & 37 & 6 & 14 & 3 \\
\hline House Wren & 8 & 3 & 14 & 6 & 5 & 0 \\
\hline Northern Cardinal & 13 & 4 & 6 & 1 & 10 & 1 \\
\hline Ovenbird & 23 & 11 & 29 & 7 & 12 & 1 \\
\hline Song Sparrow & 17 & 6 & 10 & 4 & 9 & 1 \\
\hline Swainson's Thrush & 52 & 25 & 51 & 9 & 38 & 1 \\
\hline Veery & 6 & 4 & 13 & 1 & 5 & 0 \\
\hline Wood Thrush & 12 & 4 & 5 & 2 & 6 & 0 \\
\hline Total & 371 & 132 & 297 & 72 & 178 & 14 \\
\hline
\end{tabular}

Table 2-4. Results by species. Raw data summary of birds examined, ticks collected, and blood samples collected by species in PA, NY, and WV during spring and fall migration. 


\section{Discussion}

As the prevalence of Lyme disease increases in the United States, research needs to focus on the alternative carriers that have the potential to contribute to the expansion of the disease range, including the ranges of both the Lyme pathogen (Borrelia burgdorferi) and its primary vector (Ixodes scapularis) (Bacon et al., 2008; CDC, 2016). As competent reservoirs of Borrelia burgdorferi and carriers of Ixodes scapularis ticks, songbirds have the potential to be important carriers and dispersers of the disease-causing bacteria and the primary vector host (Anderson and Magnarelli, 1984; Anderson et al., 1986; Tilly et al., 2008; Levi et al., 2016). Birds are likely also playing a vital role in maintaining the bacterium, and this study has added information about the avian capacity to carry Borrelia burgdorferi positive ticks. More critically, birds are acting as latent carriers of Borrelia burgdorferi, and the lack of Borrelia burgdoreferi positive ticks pulled from birds is not a predictor of the presence of bacterium in bird blood.

Studies have established that birds are capable of carrying ticks and introducing them to new areas (Smith et al., 1996; Rand et al., 1998; Ogden et al., 2008). Few studies have quantified the importation of ticks by birds to determine their impact on the establishment and maintenance of tick populations and the diseases that they carry, however, multiple island studies have shown that non-endemic ticks were reintroduced annually by birds (Elias et al., 2010; Rand et al., 2004). Although migrating birds were not able to maintain tick populations or the presence of tick-borne diseases in the absence of mammalian hosts, this research indicates that birds can introduce these ticks and diseases to areas where there are competent mammalian hosts. New tick introductions can lead to the spread of tick populations and the diseases that they carry. As with other studies, over $25.0 \%$ of the ticks that were collected from birds tested positive for Borrelia burgdorferi, supporting that these birds are exposed to and able to transport ticks that carry the diseasecausing bacteria (Smith et al., 1996). Also, an association was found between fat score and infestation by Borrelia positive ticks, indicating that birds with lower fat scores are more likely to be exposed to and bear a larger load of Borrelia burgdorferi positive ticks. This could be the result of decreased energy for preening in birds with poorer body condition (lower fat scores), which is supported by research on the behavioral changes associated with parasitism (Bush and Clayton, 2018). Establishing an infestation threshold (6 ticks on one bird) at which at least one of the ticks removed from the bird is Borrelia burgdorferi positive, estimates can be made about how significantly these birds are contributing to the spread of the disease based on their average tick loads. This knowledge can be used to implement management strategies focused on reducing the number of ticks in these environments because fewer ticks on these birds would decrease their likelihood of transporting a Borrelia burgdorferi positive tick and transmitting the disease.

Reservoir competency for Borrelia burgdorferi was also assessed in these birds, which was important for determining if these birds could participate in disease transmission beyond just the carrying of infected ticks (Giardina et al., 2000; Richter et al., 2000; Ginsberg et al., 2005; Levi et al., 2016)A similar prevalence of Borrelia burgdorferi was found in both non-infested and infested birds. These results also indicated that ticks on the birds do not need to test positive for Borrelia burgdorferi for the bird itself to test positive, which reveals a flaw in much of the research recently conducted on birds as carriers of Lyme disease. By only testing the ticks removed from birds rather than focusing on the bird itself as a carrier, the role that birds play in the disease cycle for Lyme disease is severely underestimated. Birds tested positive for the bacteria even if they were not infested by ticks or were infested by only Borrelia burgdorferi negative ticks at the time of capture, showing that infestation by positive ticks is not the only 
indicator of Borrelia burgdorferi positive blood in birds. In fact, none of the 6 infested birds whose blood tested positive for Borrelia burgdorferi had positive ticks on them. Also, the gray catbird showed reservoir competency in three different blood samples, despite some literature stating that they are incompetent reservoirs of Borrelia burgdorferi (Mather et al., 1989).

Birds have a diverse role in the enzootic cycle of Lyme disease. This cycle, which includes infected ticks passing the bacteria onto birds, non-infected ticks feeding on the infected birds and becoming infected, infected ticks falling off of birds to molt and feed on other species in the ecosystem, and birds introducing infected or non-infected ticks to new areas, could be a means of establishing or maintaining Lyme disease within a community. Understanding this disease cycle and the role that all of the carriers have in it could lead to better management of its spread based on the knowledge of these animals and their movements. Some potential management strategies based on these findings include; reducing tick populations in environments that birds are migrating through, implementing tick removal procedures or requirements at the various bird banding stations throughout the country, or including avian species in the pre-existing disease management strategies for mammals.

Future research should focus on testing both ticks removed from birds and blood from the birds to strengthen our understanding of the relationship between infestation and reservoir competency. Also, investigating patterns amongst infestation, positive ticks, and positive blood with other bird characteristics could help create more predictive models for determining the likelihood of infestation and exposure to disease. Lastly, genotyping the ticks that are collected from the birds to determine where they are transported to and from would greatly enhance our understanding of how important birds are in the dispersal of these vectors and associated diseases on the landscape. 


\section{References}

Anders AD, Faaborg J, and Thompson FR. Postfledgling dispersal, habitat use, and home-range size of juvenile wood thrushes. The Auk. 1998; 115(2):349-358.

Anderson JF and Magnarelli LA. Avian and mammalian hosts for spirochete-infected ticks and insects in a Lyme disease focus in Connecticut. Yale J Biol Med. 1984; 57(4):627-641.

Anderson JF, Johnson RC, Magnarelli LA, and Hyde FW. The involvement of birds in the epidemiology of the Lyme disease agent Borrelia burgdorferi. Infect Immun. 1986; 51:394-396.

Bacon RM, Kugeler KJ, Griffith KS, and Mead PS. Surveillance for Lyme disease - United States, 1992-2006. Morbidity and Mortality Weekly Report. 2008; 56:1-9.

Bates D, Machler M, Bolker BM, and Walker SC. Fitting linear mixed-effects models using lme4. Journal of Statistical Software. 2015; 67(1):1-48.

Bradley CA and Altizer S. Urbanization and the ecology of wild- life diseases. Trends Ecol Evol. 2007; 22:95-102.

Brinkerhoff RJ, Folsom-O'Keefe CM, Bent SJ, Tsao K, et al. Genotypic diversity of Borrelia burgdorferi strains detected in Ixodes scapularis larvae collected from North American songbirds. Appl Environ Microbiol. 2010; 76:8265-8268.

Brinkerhoff RJ, Folsom-O'Keefe CM, Streby HM, Bent SJ, et al. Regional variation in immature Ixodes scapularis parasitism on North American songbirds: Implications for transmission of the Lyme pathogen, Borrelia burgdorferi. J Med Entomol. 2011; 48(2):422-428.

Brinkerhoff RJ, Folsom-O'Keefe CM, Tsao K, and Diuk-Wasser MA. Do birds affect Lyme disease risk? Range expansion of the vector-borne pathogen Borrelia burgdorferi. Front Ecol Environ. 2009.

Brown, CR, Brown MB, and Rannala B. Ectoparasites reduce the long-term survival of their avian host. Proc R Soc Lond B. 1995; 262:313-319.

Burgdorfer W, Barbour AG, Hayes SF, Benach JL, et al. Lyme disease - a tick-borne spirochetosis? Science. $1982 ; 216$.

Burgdorfer W and Gage KL. Susceptibility of the black-legged tick, Ixodes scapularis, to the Lyme disease spirochete Borrelia burgdorferi. Zentralbl Bakteriol Mikrobiol Hyg. 1986; 263:15-20.

Burnham KP and Anderson DR. 2002. Model selection and multimodel inference: a practical information-theoretic approach. Springer, New York, New York, USA.

Bush SE and Clayton DH. Anti-parasite behaviour of birds. Phil Trans R Soc B. 2018; 373:20170196.

Centers for Disease Control and Prevention (CDC). Tickborne Diseases of the United States. Retrieved 
from http://www.cdc.gov/ticks/diseases/index.html. 2016.

Clayton DH, Moyer BR, Bush SE, et al. Adaptive significance of avian beak morphology for ectoparasite control. Proc R Soc Lond B. B: Biological Sciences. 2005; 272(1565):811-817.

Cohen EB, Auckland LD, Marra PP, and Hamer SA. Avian migrants facilitate invasion of neotropical ticks and tick-bonre pathogens into the United States. Appl and Environ Microbiol. 2015; 81(24):8366-8378.

Cooley RA and Kohls GM. 1945. The genus Ixodes in North America. Washington: Govt. Print. Off.

Courtney JW, Kostelnik LM, Zeidner NS, and Massung RF. Multiplex real-time PCR for detection of Anaplasma phagocytophilium and Borrelia burgdorferi. J Clin Microbiol. 2004 ;42(7):31643168.

DeLuca WV, Woodworth BK, Rimmer CC, Marra PP, et al. Transoceanic migration by a $12 \mathrm{~g}$ songbird. Biol Lett. 2015; 11:20141045.

Elias SP, Smith RP, Morris SR, Rans PW, et al. Density of Ixodes scapularis ticks on Monhegan Island after complete deer removal: A question of avian importation. J Vect Ecol. 2010; 36(1):11-23.

Gatewood AG, Liebman KA, Vourc'h G, Bunikis J, et al. Climate and tick seasonality predict Borreila burgdorferi genotype distribution. Appl Environ Microbiol. 2009; 75:2476-2483.

Giardina AR, Schmidt KA, Schauber EM, and Ostfeld RS. Modeling the role of songbirds and rodents in the ecology of Lyme disease. Canadian J of Zoology. 2000; 78:2184-97.

Ginsberg HS, Buckley PA, Balmforth MG, Zhioua E, et al. Reservoir competence of native North American birds for the Lyme disease spirochete, Borrelia burgdorferi. J Med Entomol. 2005; 42: 445-449.

Gray JS. Biology of Ixodes species ticks in relation to tick-borne zoonoses. Wien Klin Wochenschr. 2002; 114:473-478.

Hamer SA, Goldberg TL, Kitron UD, Brawn JD, et al. Wild birds and urban ecology of ticks and tickborne pathogens, Chicago, Illinois, 2005-2010. Emerg Inf Dis. 2012; 18(10): 1589-95.

Hamer SA, Hickling GJ, Sidge JL, Rosen ME, et al. Diverse Borrelia burgdorferi strains in a bird-tick cryptic cycle. Appl and Env Microbiol. 2011; 77(6):1999-2007.

Hubálek Z. An annotated checklist of pathogenic microorganisms associated with migratory birds. J Wildl Dis. 2004; 40:639-659.

Kurtenbach K, Hanincova K, Tao JI, Margos G, et al. Fundamental processes in the evolutionary ecology of Lyme borreliosis. Microbiol. 2006; 4:660-669.

Levi T, Keesing F, Holt RD, Barfield M, et al. Quantifying dilution and amplification in a community of hosts for tick-borne pathogens. Ecol Appl. 2016; 26(2):484-498. 
LoGuidice K, Ostfeld RS, Schmidt KA, and Keesing F. The ecology of infectious disease: effects of host diversity and community composition on Lyme disease risk. P Natl Acad Sci USA. 2003; 100:567-571.

Loss SR, Noden BH, Hamer GL, and Hamer SA. A quantitative synthesis of the role of birds in carrying ticks and tick-borne pathogens in North America. Oecologia. 2016; 182:947-959.

Mather TN, Telford SR $3^{\text {rd }}$, MacLachlan AB, and Spielman A. Incompetence of catbirds as reservoirs for the Lyme disease spirochete (Borrelia burgdorferi). J Parasitol. 1989; 75: 66-69.

Mazerolle MJ. AICcmodavg: Model selection and multimodel inference based on (Q)AIC(c). R package version 20-4. 2016.

Norris EN, Klompen JSH, Keirans JE, and Black IV WC. Population Genetics of Ixodes scapularis (Acari: Ixodidae) based on mitochondrial 16s and 12s genes. J Med Entomol. 1996; 33(1):78-89.

Ogden NH, Lindsay LR, Hanincova K, Barker IK, et al. Role of migratory birds in introduction and range expansion of Ixodes scapularis ticks and of Borrelia burgdorferi and Anaplasma phagocytophilum in Canada. Appl Environ Microbiol. 2008; 74:1780-1790.

Ogden NH, Maarouf A, Barker IK, Bigras-Poulin M, et al. Projections for range expansion of the Lyme disease vector Ixodes scapularis, in response to climate change. Int J Parasitol. 2006; 36:63-70.

$\mathrm{R}$ : A language and environment for statistical computing. $\mathrm{R}$ foundation for statistical computing, Vienna, Austria. R Core Team. 2014.

Rand PW, Lacombe EH, Smith RP Jr, and Ficker J. Particiation of birds (Aves) in the emergence of Lyme disease in southern Maine. J Med Entomol. 1998; 35:270-276.

Rand PW, Lubelczyk C, Holman MS, Lacombe EH, and Smith RP Jr. Abundance of Ixodes scapularis (Acari: Ixodidae) after the complete removal of deer from an isolated off shore island, endemic for Lyme disease. J Med Entomol. 2004; 41:779-784.

Richter D, Spielman A, Komar N, and Matuschka FR. Competence of American robins as reservoir hosts for Lyme disease spirochetes. Emerg Inf Dis. 2000; 6:133-138.

Schneider AC, Parker CM, Miller JR, Fredericks LP, et al. Assessint the contribution of songbirds to the movement of ticks and Borrelia burgdorferi in the Midwestern United States during fall migration. EcoHealth. 2015; 12:164-173.

Smith RP Jr., Rand PW, Lacombe EH, Morris SR, et al. Role of bird migration in the long-distance dispersal of Ixodes dammini, the vector of Lyme disease. J Infect Dis. 1996; 174:221-224.

Smith SB, Miller AC, Merchant CR, and Sankoh AF. Local site variation in stopover physiology of migrating songbirds near the south shore of Lake Ontario is linked to fruit availability and quality. Conserv Phys. 2015; 3(1): cov036. 
Stafford KC, Bladen VC, and Magnarelli LA. Ticks (Acari: Ixodidae) infesting wild birds (Aves) and white-footed mice in Lyme, CT. J Med Entomol. 1995; 32(4):453-466.

Tilly K, Rosa PA, and Stewart PE. Biology of infection with Borrelia burgdorferi. Infect Dis Clin North Am. 2008; 22(2):217-234.

Venables WN and Ripley BD. 2002. Modern Applied Statistics with S. Fourth Edition. Springer, New York. ISBN 0-387-95457-0.

Widmann RH. 2016. Forests of New York, 2015. Resource Update FS-96. Newtown Square, PA: U.S. Department of Agriculture, Forest Service, Northern Research Station. 4 p.

Young, AH, Knapp KR, Inamdar A, Rossow WB, et al. "The International Satellite Cloud Climatology Project, H-Series Climate Data Record Product," Earth System Science Data, in preparation. 2017.

Zeileis A, Kleiber C, and Jackman S. Regression models for count data in R. Journal of Statistical Software. 2008; 27(8).

Zolnierowicz KM, Ondrova-Nyklowa M, and Tobolka M. Sex differences in preening behavior in the White Stork (Ciconia ciconia). Pol J Ecol. 2016; 64:406-410. 


\section{CONCLUSION}

The main goal of these studies was to better understand the role that songbirds play in the transmission of Lyme disease to ultimately help manage and prevent exposure of humans to the disease. Although it has already been established that birds are competent reservoirs of Borrelia burgdorferi and carriers of Ixodes ticks that harbor it, this study shows that songbirds have a greater potential role in the transmission of Lyme disease than previously understood. These findings enhanced the current understanding of the role that ground-dwelling songbirds have in the transmission of Lyme disease.

First, this study determined that age, phylogenetic family, fat score, and migratory strategy are statistically significant predictors of infestation probabilities and/or tick loads, and fat score was a statistically significant predictor of Borrelia burgdorferi prevalence in ticks on birds. This indicates that there are associations between certain bird life-history characteristics and their exposure to ticks, which can be used to make predictions about the risk of human exposure to ticks and the diseases that they carry based on our understanding of these birds and their behaviors (habitat, foraging, migration). Also, the tick load threshold established in this study confirms that many species of birds are capable of contributing to the spread of Lyme disease based on what is known about their exposure to ticks and the number of ticks that they carry. Additionally, this threshold could be used to make estimates of disease prevalence in the field based on the number of ticks found on a bird. However, I still recommend testing a sample of the ticks to confirm the presence of Borrelia burgdorferi. Lastly, by demonstrating the reservoir competence of many of these species and the lack of association between infestation by a Borrelia burgdorferi positive tick and Borrelia burgdorferi positive blood from the same bird, these studies demonstrate the importance of includng the birds as carriers of the Borrelia bacterium itself rather than just carriers of its primary vector Ixodes scapularis. With these results and the understanding of these birds' movements, this research could lead to predictive models for how the disease is being spread or when and where humans and animals are at the highest risk of exposure to Lyme disease. 


\section{LITERATURE CITED}

Anders AD, Faaborg J, and Thompson FR. Postfledgling dispersal, habitat use, and home-range size of juvenile wood thrushes. The Auk. 1998; 115(2):349-358.

Anderson JF and Magnarelli LA. Avian and mammalian hosts for spirochete-infected ticks and insects in a Lyme disease focus in Connecticut. Yale J Biol Med. 1984; 57(4):627-641.

Anderson JF, Johnson RC, Magnarelli LA, and Hyde FW. The involvement of birds in the epidemiology of the Lyme disease agent Borrelia burgdorferi. Infect Immun. 1986; 51:394396.

Anderson JF. Epizootiology of Borrelia in Ixodes tick vectors and reservoir hosts. Rev of Infect Dis. 1989; 11(6):S1451-S1459.

Bacon RM, Kugeler KJ, Griffith KS, and Mead PS. Surveillance for Lyme disease - United States, 1992-2006. Morbidity and Mortality Weekly Report. 2008; 56:1-9.

Barbour AG and Fish D. The biological and social phenomenon of Lyme disease. Science. 1993; 260:1610-1616.

Bates D, Machler M, Bolker BM and Walker SC. Fitting linear mixed-effects models using lme4. Journal of Statistical Software. 2015; 67(1):1-48.

Battaly GR, Fish D, and Dowler RC. The seasonal occurrence of Ixodes dammini and Ixodes dentatus (Acari: Ixodidae) on birds in a Lyme disease endemic area of southeastern New York State. J New York Entomol Soc. 1987; 461-468.

Baum SE, Machalaba C, Daszak P, Salerno RH, et al. Evaluating one health: Are we demonstrating effectiveness? One Health. 2017; 3:5-10.

Beddall BG. Range expansion of the cardinal and other birds in the northeastern states. Wilson Bull. $1963 ; 75: 140-158$.

Bradley CA and Altizer S. Urbanization and the ecology of wild- life diseases. Trends Ecol Evol. 2007; 22:95-102.

Brinkerhoff RJ, Folsom-O'Keefe CM, Bent SJ, Tsao K, et al. Genotypic diversity of Borrelia burgdorferi strains detected in Ixodes scapularis larvae collected from North American songbirds. Appl Environ Microbiol. 2010; 76:8265-8268.

Brinkerhoff RJ, Folsom-O'Keefe CM, Streby HM, Bent SJ, et al. Regional variation in immature Ixodes scapularis parasitism on North American songbirds: Implications for transmission of the Lyme pathogen, Borrelia burgdorferi. J Med Entomol. 2011; 48(2):422-428. 
Brinkerhoff RJ, Folsom-O'Keefe CM, Tsao K, and Diuk-Wasser MA. Do birds affect Lyme disease risk? Range expansion of the vector-borne pathogen Borrelia burgdorferi. Front Ecol Environ. 2009.

Brown, CR, Brown MB, and Rannala B. Ectoparasites reduce the long-term survival of their avian host. Proc R Soc Lond B. 1995; 262:313-319.

Burgdorfer W, Barbour AG, Hayes SF, Benach JL, et al. Lyme disease - a tick-borne spirochetosis? Science. $1982 ; 216$.

Burgdorfer W and Gage KL. Susceptibility of the black-legged tick, Ixodes scapularis, to the Lyme disease spirochete Borrelia burgdorferi. Zentralbl Bakteriol Mikrobiol Hyg. 1986; 263:15-20.

Burgdorfer W, Hayes SF, and Corwin D. Pathophysiology of the Lyme disease spirochete, Borrelia burgdorferi, in Ixodid ticks. RevInfect Dis. 1989; 11(6):S1442-1450.

Burnham KP and Anderson DR. 2002. Model selection and multimodel inference: a practical information-theoretic approach. Springer, New York, New York, USA.

Bush SE and Clayton DH. Anti-parasite behaviour of birds. Phil Trans R Soc B. 2018; 373:20170196.

Centers for Disease Control and Prevention (CDC). Tickborne Diseases of the United States. Retrieved from http://www.cdc.gov/ticks/diseases/index.html. 2016.

Clayton DH, Moyer BR, Bush SE, et al. Adaptive significance of avian beak morphology for ectoparasite control. Proc R Soc Lond B. B: Biological Sciences. 2005; 272(1565):811-817.

Cohen EB, Auckland LD, Marra PP, and Hamer SA. Avian migrants facilitate invasion of neotropical ticks and tick-bonre pathogens into the United States. Appl and Environ Microbiol. 2015 ;81(24):8366-8378.

Cooley RA and Kohls GM. 1945. The genus Ixodes in North America. Washington: Govt. Print. Off.

Comstedt P, Bergstrom S, Olsen B, Garpmo U, et al. Migratory Passerine Birds as Reservoirs of Lyme Borreliosis in Europe. Emerg Infect Dis. 2006; 12(7):1087-1095.

Coristine LE and Kerr JT. Temperature-related geographical shifts among passerines: contrasting processes along poleward and equatorward range margins. Ecol and Evol. 2015 ;5(22):51625176.

Cornell Lab of Ornithology. 2014. All About Birds. All About Bird Biology <birdbiology.org>. Cornell Lab of Ornithology, Ithaca, New York. 
Courtney JW, Kostelnik LM, Zeidner NS, and Massung RF. Multiplex real-time PCR for detection of Anaplasma phagocytophilium and Borrelia burgdorferi. J Clin Microbiol. 2004 ;42(7):3164-3168.

Dantas-Torres F, Chomel BB, and Otranto D. Tick and tick-borne disease: A One Health perspective. Trends in Parasitol. 2012; 8(10):437-46.

De Oliveira SV, Dos Santos J, Gustavo Aver, Correa LC, et al. Serological evidence of Lyme disease and possibleintroduction of Borrelia along migratory bird routes in Brazil. Vector Biol J. 2018; 3:1-4.

DeLuca WV, Woodworth BK, Rimmer CC, Marra PP, et al. Transoceanic migration by a $12 \mathrm{~g}$ songbird. Biol Lett. 2015; 11:20141045.

Deppe JL, Ward MP, Bolus RT, Diehl RH, et al. Fat, weather, and date affect migratory songbirds' departure decisions, routes, and time it takes to cross the Gulf of Mexico. PNAS Plus. 2015; E6331-E6338.

Donahue JG, Peisman J, and Spielman A. Reservoir competence of white-footed mice for Lyme disease spirohetes. Am J Trop Med Hyg. 1987; 36:92-96.

Dubska L, Literak I, Kocianova E, Taragelova V, et al. Differential role of passerine birds in distribution of Borrelia spirochetes, based on data from ticks collected from birds during the postbreeding migration period in central Europe. Appl. Environ. Microbiol. 2009; 75:596602.

Elias SP, Smith RP, Morris SR, Rans PW, et al. Density of Ixodes scapularis ticks on Monhegan Island after complete deer removal: A question of avian importation. J Vect Ecol. 2010; 36(1):11-23.

Food and Agriculture Organization of the United Nations, One Health: Food and Agriculture of the United Nations Strategic Action Plan, 2011 (Rome).

Frank D, Fish D, and Moy F. Landscape features associated with Lyme disease risk in a suburban residential environment. Landscape Ecology. 1998; 13:27-36.

Gatewood AG, Liebman KA, Vourc'h G, Bunikis J, et al. Climate and tick seasonality predict Borreila burgdorferi genotype distribution. Appl Environ Microbiol. 2009; 75:2476-2483.

Giardina AR, Schmidt KA, Schauber EM, and Ostfeld RS. Modeling the role of songbirds and rodents in the ecology of Lyme disease. Canadian J of Zoology. 2000; 78:2184-97.

Ginsberg HS, Buckley PA, Balmforth MG, Zhioua E, et al. Reservoir competence of native North American birds for the Lyme disease spirochete, Borrelia burgdorferi. J Med Entomol. 2005; 42: 445-449.

Gray JS. Biology of Ixodes species ticks in relation to tick-borne zoonoses. Wien Klin Wochenschr. 
$2002 ; 114: 473-478$.

Guzy MJ and Ritchison G. Common Yellowthroat (Geothlypis trichas). In The Birds of North America, No. 448 (A. Poole and F. Gill, eds.). The Birds of North America Online, Ithaca, New York. 1999.

Hamer SA, Goldberg TL, Kitron UD, Brawn JD, et al. Wild birds and urban ecology of ticks and tick-borne pathogens, Chicago, Illinois, 2005-2010. Emerg Inf Dis. 2012; 18(10): 1589-95.

Hamer SA, Hickling GJ, Sidge JL, Rosen ME, et al. Diverse Borrelia burgdorferi strains in a birdtick cryptic cycle. Appl and Env Microbiol. 2011; 77(6):1999-2007.

Harvell CD, Mitchell CE, Ward JR, Altizer S, et al. Climate warming and disease risks for terrestrial and marine biota. Science. 2002; 296(5576):2158-2162.

Hitch AT and Leberg PL. Breeding distributions of North American bird species moving north as a result of climate change. Conserv Biol. 2007; 21(2):534-539.

Hubálek Z. An annotated checklist of pathogenic microorganisms associated with migratory birds. J Wildl Dis. 2004; 40:639-659.

Keesing F, Holt RD, and Ostfeld RS. Effects of species diversity on disease risk. Ecol Lett. 2006; 9(4):485-498.

Kilpatrick AM, Chmura AA, Gibbons DW, Fleischer RC, et al. Predicting the global spread of H5N1 avian influenza. Proc Natl Acad Sci USA. 2006; 103:19368-19373.

Kovats RS, Campbell-Lendrum DH, McMichael AJ, Woodward A, et al. The effects of climate change: do they include changes in vector-borne disease? Phil Trans R Soc Lond B. 2001; 356:1057-1068.

Kurtenbach K, Hanincova K, Tao JI, Margos G, et al. Fundamental processes in the evolutionary ecology of Lyme borreliosis. Microbiol. 2006; 4:660-669.

Levi T, Keesing F, Holt RD, Barfield M, et al. Quantifying dilution and amplification in a community of hosts for tick-borne pathogens. Ecol Appl. 2016; 26(2):484-498.

LoGuidice K, Ostfeld RS, Schmidt KA, and Keesing F. The ecology of infectious disease: effects of host diversity and community composition on Lyme disease risk. P Natl Acad Sci USA. 2003; 100:567-571.

Loss SR, Noden BH, Hamer GL, and Hamer SA. A quantitative synthesis of the role of birds in carrying ticks and tick-borne pathogens in North America. Oecologia. 2016; 182:947-959.

Mannelli A, Kitron U, Jones CJ, and Slajchert TL. Influence of season and habitat of Ixodes scapularis infestation on white-footed mice in northwestern Illinois. J Parasitol. 1994; 80(6):1038-1042. 
Mather TN, Telford SR $3^{\text {rd }}$, MacLachlan AB, and Spielman A. Incompetence of catbirds as reservoirs for the Lyme disease spirochete (Borrelia burgdorferi). J Parasitol. 1989; 75: 6669.

Mazerolle MJ. AICcmodavg: Model selection and multimodel inference based on (Q)AIC(c). R package version 20-4. 2016.

Norris EN, Klompen JSH, Keirans JE, and Black IV WC. Population Genetics of Ixodes scapularis (Acari: Ixodidae) based on mitochondrial 16s and 12s genes. J Med Entomol. 1996; 33(1):78-89.

O'Connor J, Sulloway F, Robertson J, and Kleindorfer S. Philornis downsi parasitism is the primary cause of nestling mortality in the critically endangered Darwin's medium tree finch (Camarhynchus pauper). Biodivers and Conserv. 2009; 19:853-866.

Ogden NH, Bigras-Poulin M, O'Callaghan CJ, et al. A dynamic population model to investigate effects of climate on geographic range and seasonality of tick Ixodes scapularis. Int J Parasitol. 2005; 35:375-389.

Ogden NH, Lindsay LR, Beauchamp G, Charron D, et al. Investigation of the relationships between temperature and development rates of the tick Ixodes scapularis (Acari: Ixodidae) in the laboratory and field. J Med Entomol. 2004; 41: 622-633.

Ogden NH, Lindsay LR, Hanincova K, Barker IK, et al. Role of migratory birds in introduction and range expansion of Ixodes scapularis ticks and of Borrelia burgdorferi and Anaplasma phagocytophilum in Canada. Appl Environ Microbiol. 2008; 74:1780-1790.

Ogden NH, Maarouf A, Barker IK, Bigras-Poulin M, et al. Projections for range expansion of the Lyme disease vector Ixodes scapularis, in response to climate change. Int J Parasitol. 2006; 36:63-70.

Ostfeld RS. Lyme Disease: The Ecology of a Complex System. Oxford University Press, New York. 2011.

Poupon MA, Lommano E, Humair PF, Douet V, et al. Prevalence of Borrelia burgdorferi sensu lato in ticks collected from migratory birds in Switzerland. Appl Environ Microbiol. 2006; 72:976-979.

Pyle, P. 1997. Identification guide to North American birds. Slate Creek Press, Bolinas, CA.

R: A language and environment for statistical computing. $\mathrm{R}$ foundation for statistical computing, Vienna, Austria. R Core Team. 2014.

Rand PW, Lacombe EH, Smith RP Jr, and Ficker J. Particiation of birds (Aves) in the emergence of Lyme disease in southern Maine. J Med Entomol. 1998; 35:270-276. 
Rand PW, Lubelczyk C, Holman MS, Lacombe EH, and Smith RP Jr. Abundance of Ixodes scapularis (Acari: Ixodidae) after the complete removal of deer from an isolated off shore island, endemic for Lyme disease. J Med Entomol. 2004; 41:779-784.

Randolph SE. Ticks are not insects: consequences of contrasting vector biology for transmission potential. Parasitol Today. 1998; 14:186-192.

Rappole JH and Hubálek Z. Migratory birds and West Nile virus. J Appl Microbiol. 2003; 94:47S$58 \mathrm{~S}$.

Richter D, Spielman A, Komar N, and Matuschka FR. Competence of American robins as reservoir hosts for Lyme disease spirochetes. Emerg Inf Dis. 2000; 6:133-138.

Schneider AC, Parker CM, Miller JR, Fredericks LP, et al. Assessing the contribution of songbirds to the movement of ticks and Borrelia burgdorferi in the Midwestern United States during fall migration. EcoHealth. 2015; 12:164-173.

Scott JD, Fernando K, Banerjee SN, Durden La, et al. Birds disperse ixodid (Acari: Ixodidae) and Borrelia burgdorferi-infected ticks in Canada. J Med Entomol. 2001; 38:493-500.

Smith RP Jr., Rand PW, Lacombe EH, Morris SR, et al. Role of bird migration in the long-distance dispersal of Ixodes dammini, the vector of Lyme disease. J Infect Dis. 1996; 174:221-224.

Smith SB, Miller AC, Merchant CR, and Sankoh AF. Local site variation in stopover physiology of migrating songbirds near the south shore of Lake Ontario is linked to fruit availability and quality. Conserv Phys. 2015; 3(1): cov036.

Sonenshine DE. Biology of Ticks. Oxford University Press, New Yorl. 1991.

Stafford KC, Bladen VC, and Magnarelli LA. Ticks (Acari: Ixodidae) infesting wild birds (Aves) and white-footed mice in Lyme, CT. J Med Entomol. 1995; 32(4):453-466.

Stickel LF. Home range and travels. Amer Soc Mamm. 1968; 2:373-411.

Stokes ME, Davis CS, and Koch GG. 2012. Categorical Data Analysis using SAS, Third Edition. Cary, NC: SAS Institute Inc.

Sutherst RW. Global change and human vulnerability to vector-borne diseases. Clin Microbiol Rev. 2004; 17(1):136-173.

Telford SR, Mather TN, Moore SI, Wilson ML, et al. Incompetence of deer as reservoirs of the Lyme disease spirochete. Am J Trop Med Hyg. 1988; 39:105-109.

Tilly K, Rosa PA, and Stewart PE. Biology of infection with Borrelia burgdorferi. Infect Dis Clin North Am. 2008; 22(2):217-234. 
Tran PM and Waller L. Effects of landscape fragmentation and climate on Lyme disease incidence in the northeastern United States. EcoHealth. 2013;10:394-404.

Vanwambeke SO, Šumilo D, Bormane A, Lambin EF, et al. Landscape predictors of tick-borne encephalitis in Latvia: land cover, land use, and land ownership. Vector-Borne Zoonotic Dis. 2010; 10:497-506.

Venables WN and Ripley BD. 2002. Modern Applied Statistics with S. Fourth Edition. Springer, New York. ISBN 0-387-95457-0.

Widmann RH. 2016. Forests of New York, 2015. Resource Update FS-96. Newtown Square, PA: U.S. Department of Agriculture, Forest Service, Northern Research Station. 4 p.

Wilson ML and Spielman A. Seasonal activity of immature Ixodes dammini (Acari: Ixodidae). J Med Entomol. 1985; 26:408-414.

Young, AH, Knapp KR, Inamdar A, Rossow WB, et al. "The International Satellite Cloud Climatology Project, H-Series Climate Data Record Product," Earth System Science Data, in preparation. 2017.

Yuval B and Spielman A. Duration and regulation of the developmental cycle of Ixodes dammini (Acari: Ixodidae). J Med Entomol. 1990; 27:196-201.

Zeileis A, Kleiber C, and Jackman S. Regression models for count data in R. Journal of Statistical Software. 2008; 27(8).

Zinsstag J, Schelling E, Wyss K, and Mahamat MB. Potential of cooperation between human and animal health to strengthen health systems. Lancet. 2005; 366(9503):2142-2145.

Zolnierowicz KM, Ondrova-Nyklowa M, and Tobolka M. Sex differences in preening behavior in the White Stork (Ciconia ciconia). Pol J Ecol. 2016; 64:406-410. 